

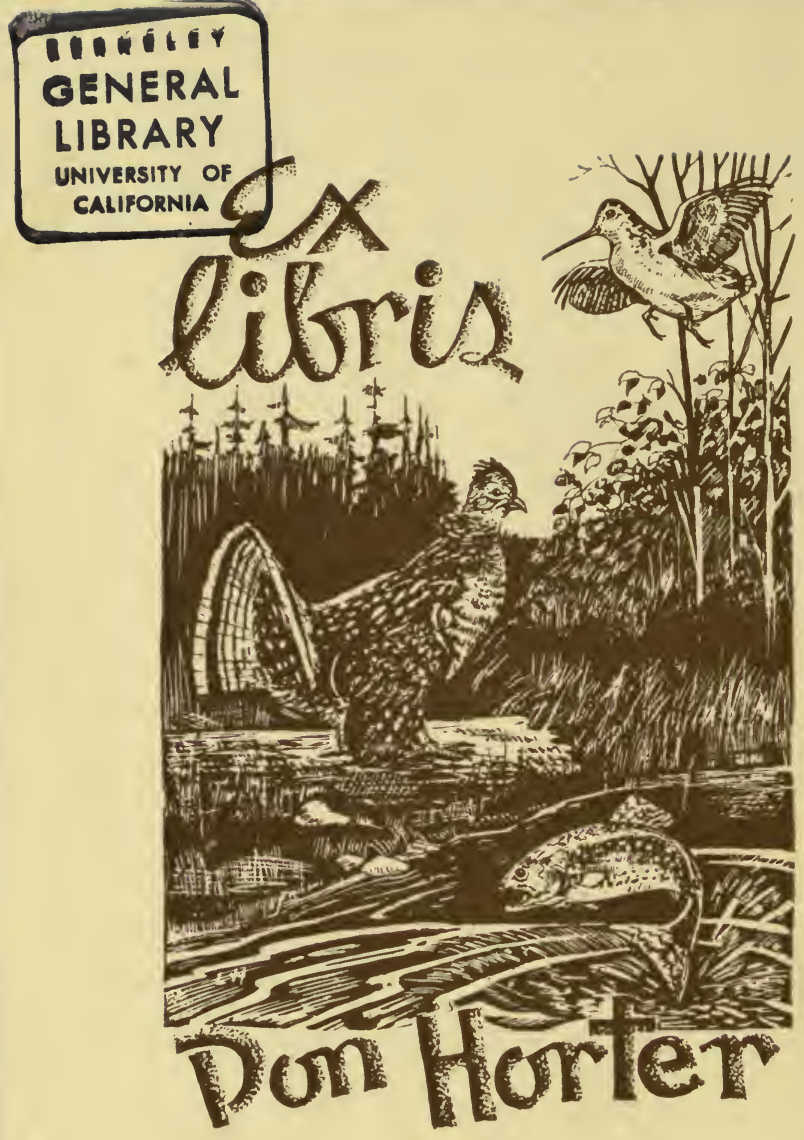

E. CHALMERS-HALLAM 
SPINNING AND TROLLING. 
Digitized by the Internet Archive in 2007 with funding from Microsoft Corporation 



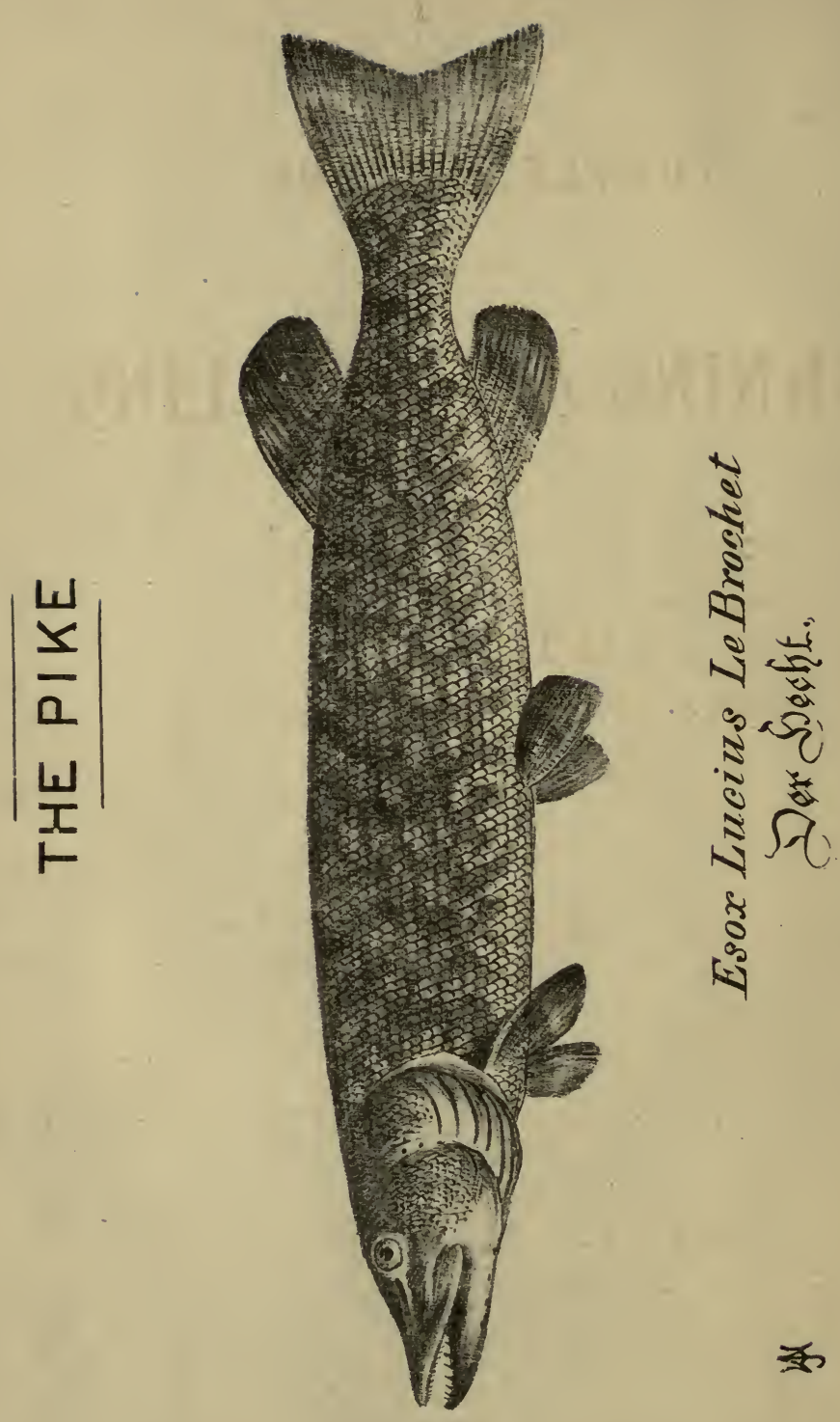




\section{A \\ COMPLETE GUIDE}

To

\section{SPINNING AND TROLLING.}

BY

“O TTER,"

AUTHOR OF “THE MODERN ANGLER," ETC., ETC.

H.J.

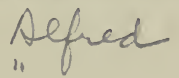

NEW EDITION.

LONDON :

A LFRED AND SON,

20, Moorgate Street.

[All-rights reserved.] 
Hazell, Watson, and Viney, Printers, London and Aylesbury. 


\section{P R E F A C E.}

SinCE the first appearance of my "Guide to Spinning and Trolling," in I859, I am happy to say it has worked its way through several editions; but there being now some extra patterns of tackle, etc., not in existence at that time, I have considered it advisable to take the present opportunity of revising it, and adding thereto illustrations and descriptions of such new tackle and baits as are really useful to the practical Angler; for though I describe what I use and find most killing myself, yet I do not pin my faith to one particular tackle, and ignore everything else, but am always ready to try other styles, and on finding them successful, do equal justice to them, and note them accordingly.

Chiswick, W.

Fanuary, 1878 . 



\title{
CONTENTS.
}

\author{
CHAPTER I. *
}

THE PIKE (ESOX LUCIUS), WHERE FOUND AND WHEN IN SEASON-ARTIFICIAL FLY FOR PIKE . . . I

CHAPTER II.

THE SPINNING ROD-WINCH-LINE-TRACE-FLIGHT OF HOOKS-HOOKS-SPINNING TACKLE • • 5

\section{CHAPTER III.}

ARTIFICIAL BAITS-CASE FOR SPINNING TACKLE, ETC.FISH BAG-LANDING NET AND GAFF HOOK .

\section{CHAPTER IV.}

INSTRUCTIONS IN SPINNING-THROWING THE BAITSTRIKING, PLAYING, AND LANDING THE FISH • 30

CHAPTER V.

LIVE-BAIT FISHING-THE ROD, WINCH, AND LINE-FLOAT -TRACE-LIVE-BAIT HOOKS, AND HOW TO BAIT THEM-THE PATERNOSTER-BAITS AND KETTLEIMPROVED BAIT-CAN • . . . $\quad 34$ 


\section{CHAPTER VI.}

THE BANK RUNNER, TRIMMER, ETC.

CHAPTER VII.

WHEN, AND HOW, TO FISH WITH LIVE-BAIT FOR PIKE-

CHAPTER VIII.

TROLLING-THE ROD, WINCH, LINE, AND TRACE-GORGEHOOK, AND HOW TO BAIT IT-WEED-HOOK-SPEARGORGE-GORGE-BAITS .

CHAPTER IX.

HOW TO WORK THE GORGE-BAIT-DISTANCE TO THROW

- TIME TO ALLOW FOR POUCHING, ETC

\section{CHAPTER X.}

SNAP-FISHING - THE ROD, WINCH, LINE, AND TRACETHE LIVE-BAIT SNAP-SPRING-SNAP-DEAD-SNAP, ETC.

\section{CHAPTER XI.}

SPINNING FOR TROUT AND PERCH-THE ROD AND TACKLE REQUIRED-BAITS, ETC. • . . . . . 68 


\section{SPINNING AND TROLLING.}

\section{CHAPTER I.}

THE PIKE (ESOX LUCYUS), WHERE FOUND AND WHEN IN SEASON--ARTIFICIAL FLY FOR PIKE.

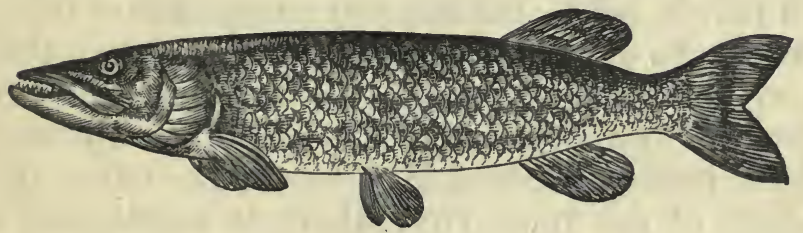

Esox Lucius.

The Pike is one of the most voracious of freshwater fish, having a flattish head, the underjaw rather longer than the upper one, and turning up slightly at the point; the mouth is immensely large, and thickly studded with teeth. The body is long, with small hard scales; when in season, the back is of a greenish gold colour, shaded into a creamy white under the belly, and beautifully marked 
on the back and sides with large yellowish spots; and when at home amongst the weeds, he is hardly to be distinguished in the wavy masses of verdure around him. His eyes are bright yellow, so placed as to enable him to see what passes above. The fins and tail are a dark purply colour, marked with dark wavy lines. When young, and up to four or five pounds in weight, he is called a Jack; and when at all hungry, nothing comes amiss to him; I have had Jack a foot in length seize a bait of half their length, and allow themselves to be lifted out of the water, rather than release their prey.

The Pike is found almost all over Europe, in ponds, lakes, canals, and rivers, where there are beds of weeds, and will under favourable circumstances attain to an extremely heavy weight and great age. In this country they have rarely exceeded eighty pounds; but in the Field of 9 th June, 1877 , there is mention of a monster which weighed a hundred and thirty pounds being caught in the Lake of Constance. The largest I have taken weighed twenty-two pounds; this I caught in the Thames at Great Marlow, in October I868, with the live-bait-snap drawn at page 62, working it through and along the edges of the weed-beds in the centre of the river.

From March to the end of June, Jack are out of season, when they resort to back waters that have a direct communication with the 
main stream, or to the stillest parts of the river, for the purpose of spawning, after which they remain for some time long and thin; the various spots and golden tinge on their sides and back then lose much of their brilliancy, and their heads appear unusually large through their having then lost that depth and rotundity of body (especially about the vent fin) which they possess when in full season; at such times the small ones take the bait eagerly, but are only fit to be returned to the water.

From July (on the first of which month Jackfishing generally commences) to October, they are usually found near or amongst waterdocks, sedges, or flag-weeds. They are seldom found where the stream is very rapid, but a retreat in the vicinity of a whirlpool or sharp bend is a favourite locality for them. In rivers, about the middle of September, when the weeds are rotting, by dropping down the stream quietly in a punt, the Jack may be observed lying among the weeds basking in the sun; they then seem too lazy to take the bait, for it is not unusual to see numerous small fish swimming and playing around this deadly enemy of the finny tribe without his taking the trouble to disturb them. As winter approaches they retire into the deeps under clay banks, or where bushes hang over the water, and where stumps and roots of trees offer them a strong hold. At 
such times a very-large artificial dragon-fly will be found a first-rate bait for large Pike. It is to be used somewhat like the spinning bait, but without any weight on the line, and is to be worked on or near the top of the water. In lakes and large ponds it is an excellent bait.

The most favourable weather for spinning, or, indeed, for any description of Jack-fishing, is when a slight breeze blows from the southwest, sufficient to ripple the water, and the day is cloudy and dull; at such times keep the wind as much as possible at your back. Thick water is not favourable for spinning, for during a flood, which causes a coloured water, Jack and Pike keep close in-shore among the rushes and sedges which grow near the banks, or in the still bends of rivers, to keep out of the rapid current, where they remain almost stationary until the waters clear and subside. The angler who chooses to try for them then must spin close to the weeds, or he will seldom move a fish; but immediately the water clears, then comes the spinner's turn, for the Pike and Jack having been for some time on short allowance, are then bold, voracious, and fearlessly take the spinning bait.

And here I may mention that I consider the best way of cooking Pike is to split them down the back after being properly scaled and cleaned, then take out the long back-bone 


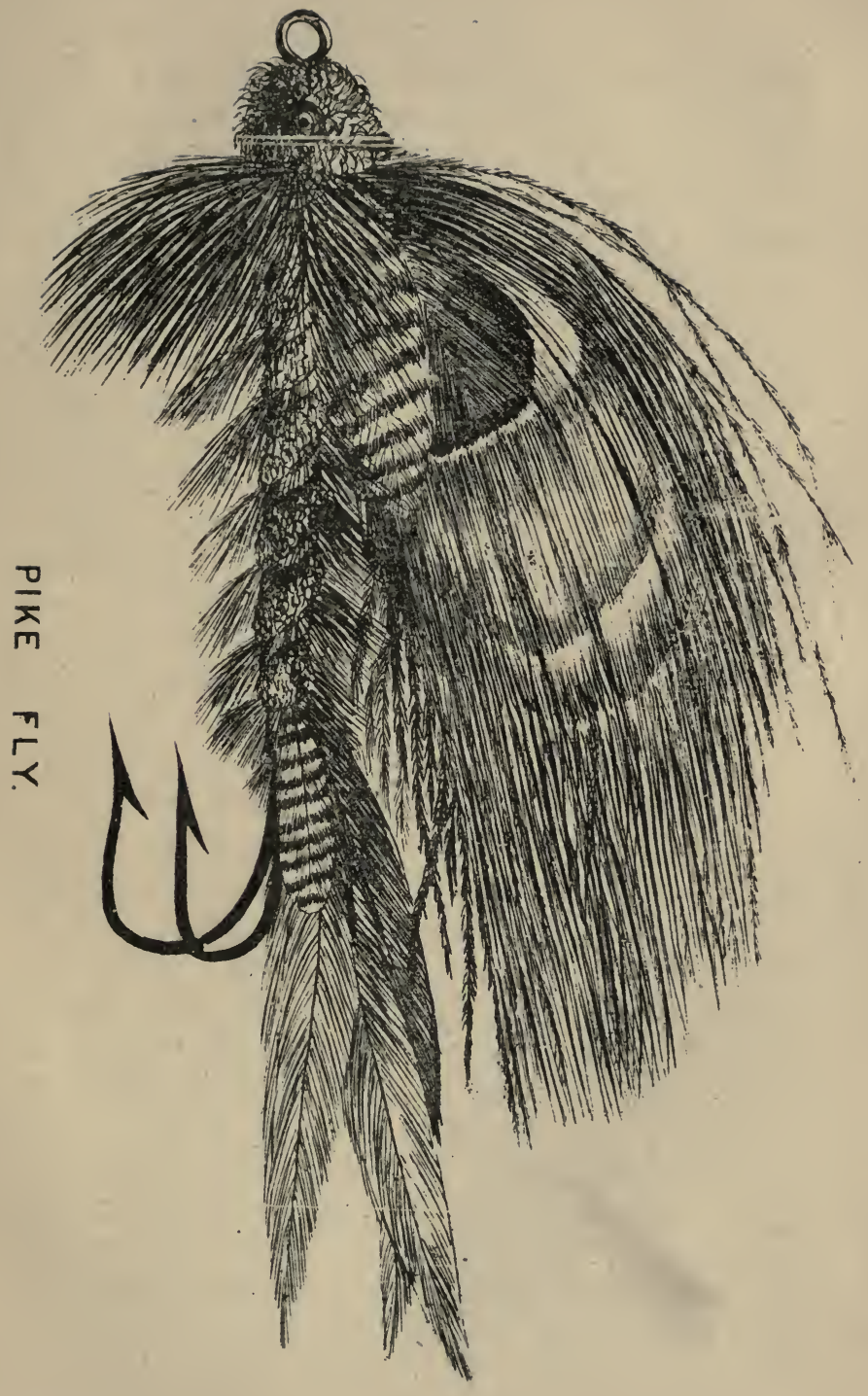



with as many of the side-bones as possible; if large, cut in fillets, and fry with egg and bread-crumbs; it should be crisp and richly browned. If intended to be eaten hot, it should be really hot, not half cold. Talleyrand was of this opinion. When dining one day with the Minister of Finance, a fine Carp was placed opposite Talleyrand, but, unfortunately, nearly cold. The financier remarked, "That is a splendid Carp: how do you like it? It came from my estate of Vir-sur-Aisne:" "Did it?" said Talleyrand; slyly adding, "but why did you not have it cooked here?"

\section{CHAPTER II.}

THE SPINNING ROD-WINCH-LINE-TRACE-FLIGHT OF HOOKS-HOOKS-SPINNING TACKLE.

THE art of Jack-fishing is commonly termed TROLLING, but this branch of angling is more properly divided and described by anglers under the four following heads, viz., SPINNING, LIVE-BAITING, TROLLING, and SN $\Lambda$ P-FISHING. Spinning means the art of taking Pike, Jack, or other fish with a bait to which is communicated a revolving or spinning motion when it is drawn through the water; live-baiting, when 
a float is used to the line and a live fish for the bait; trolling, in the limited sense of the word, is understood to mean taking Pike or Jack with a gorge hook; and snap-fishing, when the angler uses hooks of such a description, that immediately he feels a bite, if he is fishing without a float, or sees a run if he is fishing with a float, he strikes sharply, without allowing the fish time to pouch.

Spinning is by far the most scientific and interesting method of fishing for Pike, as it requires some amount of muscular exertion to practise it properly. Trout, Pike, and Perch, of all sizes, but generally the largest, are caught by spinning-either the natural fish or the artificial pectoral-fin bait being used; with the latter, however, I have often taken the best fish.

The rod I recommend for spinning is of mottled East India cane, from twelve to thirteen feet in length. It is made in four pieces, so as to close up in a partition case, in a compact form for travelling, having a couple of extra tops, in case of breakage. All the tops should be made of lancewood, and should vary in length, so as to stiffen the action of the rod when requisite. The shoulders of each joint should be double-brazed; the plain shoulders almost invariably sticking in the ferule of the next joint, in wet weather, in consequence of the wood swelling, and causing considerable trouble to take the rod to pieces after use. 
When this occurs, any difficulty in taking the rod to pieces, arising from this cause, may be obviated by warming the long ferule in the flame of a candle; when cold, it may easily be separated. The rod should also be fitted with strong fixed upright rings. The rings at the end of the tops should be of steel, as the constant friction of the line in spinning soon wears away or cuts through any other metal. The same remark applies to the large ring on the butt, which should also be of steel, fitted so as to run round easily in a brass collar, as this ring receives an equal amount of work with the end ring on the top; for when the line has once cut into or notched the rings, they, in return, wear away the line.

Besides the spinning rods which are made of mottled bamboo, there are others of hickory, having the butt-piece of ash and the tops of lancewood, either made entirely of that wood or with a piece of bamboo spliced at the end. These are first-rate rods for heavy fishing, or for rough work, but I prefer the mottled cane, as much for the handsome appearance as for the difference in weight.

The winch should be either entirely a plain one, or what is called a plain check, as a multiplier is not required for Jack-fishing. I prefer the check-winch bronzed, as I have a great objection to the glitter of bright brass on the water. Notice a fisherman with a bright winch on his rod when the sun is shining, and 
you can see the glitter for a considerable distance, and I believe the fish see it as plainly; but if the winch is bronzed, you at once do away with the glare.

The improved bronzed winches are amongst the latest improvements in the angler's equipment; their advantages are, extreme lightness, absence of the annoying glitter of the brass, and instead of the handle being made in the old style, it is fixed to and turns with one plate of the winch, thus preventing the line catching round the handle and locking the winch.

In addition to the brass and bronzed winches, there are others of hard wood; some fishermen prefer these. Instead of allowing the line, in spinning, to lay at their feet in the usual manner, they throw the line directly from the winch, using rather a long rod, and wind it in again on to the winch, instead of drawing it in with the hand. But as the wooden winches, or reels, run very easy, they require considerable care in use; for if the line is thrown from them with the least jerk, when the bait has dropped in the water and the line stopped running, the winch will continue running and wind the line the reverse way, often entangling it and getting it into knots. These winches, however, through running easy, are of considerable advantage in other descriptions of Jack-fishing, as will be seen in Chapter V., on live-bait fishing. 
We next come to the line, which should be from sixty to a hundred yards long, of the best eight-plait silk, rather fine than otherwise, so as to make as little show as possible in the water. It should be prepared with waterproof dressing, which prevents the line kinking, as it is impossible to throw a spinning-bait properly with a line that kinks or curls up in knots, as the undressed lines invariably do, as soon as they get wet. A careful spinneral ways dries his line well after use, and before putting it away, to prevent rotting.

The next thing required is the trace, which is fastened to the line thus,

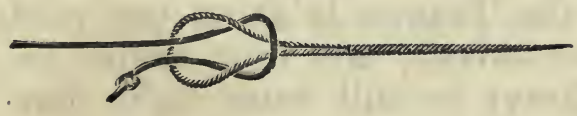

the end of the line being first knotted, to pervent it slipping when wet. The trace should be of moderate-sized gimp, with from two to four swivels, and about three feet in length; the weight required on it to sink the spinningbait will vary, of course, considerably, according to the water in which it is to be used; as a trace which would be rather heavy for still water, such as a lake or large pond, unless very deep, would be much too light for a strong stream, such as is found in some parts of the Thames and similar rivers. For fishing at the tails of weirs (where I have occasionally taken 
good Pike) heavy traces are required, although great care must be taken, if the fisherman is above or on a weir, that the bait does not catch the under-current, as it is almost certain, in this case, to foul, and will cause considerable trouble to extricate, in addition to a great loss of time, if the fish are on the feed; by judicious handling, however, and by slightly raising the top of the rod, fouling may be avoided. For my own part, I prefer the largest salmongut, slightly coloured, for the material of the trace, as it is quite as strong as gimp, if not stronger, (still using moderate-sized gimp for the flight of hooks or artificial bait,) besides being transparent in the water. The trace I use in the Thames is about two yards long, with five swivels, and from twelve to sixteen large shots; in still water eight shots would be quite sufficient.

An extremely useful weight for the trace is that known as the Field lead, so called from being originated by one of the editors of that celebrated sporting newspaper. A sketch is annexed; and it will be observed that the lead is made so that all the weight is on the under side, the upper side being just thick enough to cover the hole through which the gut or gimp is passed; the swivels are between the bait and the lead; and the weight being entirely underneath the line, this is prevented kinking or turning round when in use. It is much used in trailing; and for the Thames or 
similar large rivers I prefer it hung beneath the trace on a wire, rendering it more effectual for the purpose ;

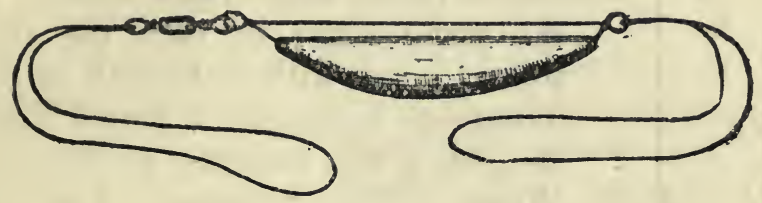

three or four swivels being used between the lead and the bait. It is a good plan to have the trace in three parts, the hanging lead being of course the centre part, so that the weight of this may be changed according to the strength of the stream.

The following trace will be found very useful when extra weight is required: from six to twelve drilled shots are strung on a short piece of gimp, the ends of which are then fastened to a couple of swivels; to each of these is attached a large loop either of salmon gut or yellow gimp, and the trace is ready for use.

Next to the trace comes the flight of hooks, of which there are a great variety. The one I use consists of three triangle hooks, a sliding lip hook, and a reverse hook, mounted on yellow gimp, as in the sketch, the length of the flight, of course, to be in proportion to the bait. 


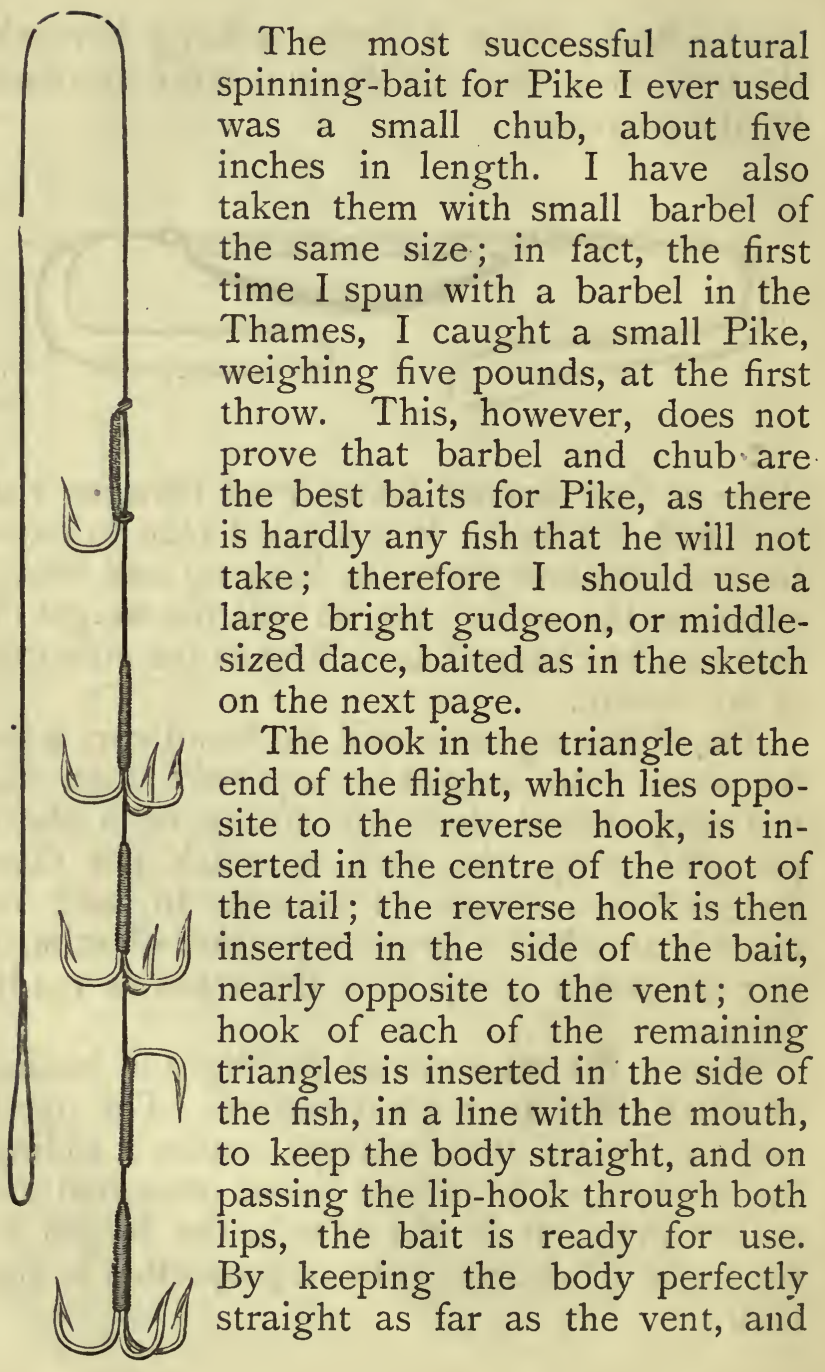



the tail curved almost at right angles to the body, the bait will spin true when drawn through the water; although some anglers prefer the bait to 'wobble,' considering that in that state it more resembles a wounded fish (which I believe the spinning bait is intended to represent) than when it spins straight.

Probably amongst my readers very few, if any, have ever been privileged to thoroughly inspect a hook factory. Where " doctors differ," how very great is the difference of opinion upon the shape of a hook: each particular bend has its own particular admirers; one will tell you that a "Limerick" should be used for every fish; another,

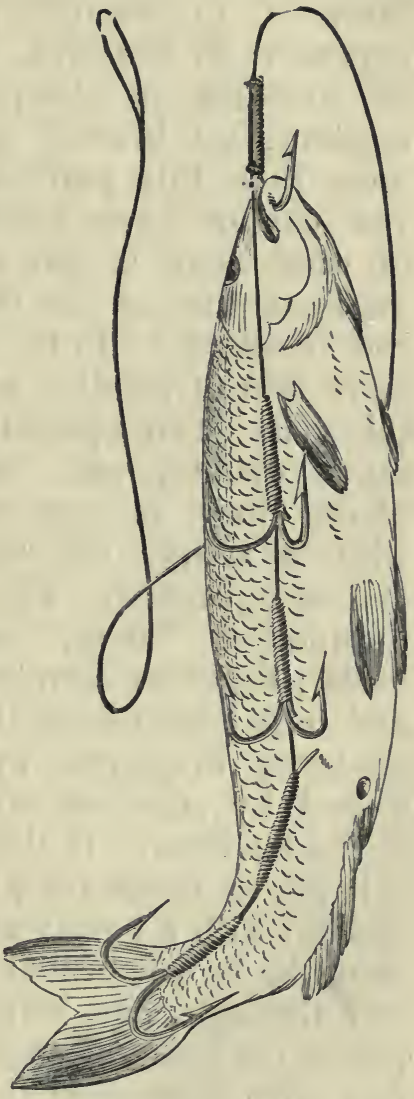
that unless you stick to a "sneck" you must never expect to hook a fish, much less to land one; and so on, through all the different and 
almost endless varieties of shape and make, all of which have their own admirers. Now there is, in the first place, no economy so expensive in the end, or so delusive, as that of investing in cheap hooks. There is, in angling, no branch of more direct importance than this particular one of hooks. If you cannot have confidence in your hook, of what avail is the most perfect skill and manipulation, or the most artistically finished rod or winch? In the manufacture of hooks, as in that of needles, each department undertakes its own special work, which is kept quite distinct and separate. In the first place, there is one department where the wire is simply cut to the required length and straightened. The wires are then passed to another "shop," where they receive the barbs; these are simply cut with a sharp knife, and it is astonishing the amount of skill and dexterity displayed by the barb-cutters acquired by constant attention to that portion of the business. If the barb is cut too deep, it is apt to break off when the point comes in contact with a bone; and if it is not cut deep enough, it will probably cause the loss of a fish through not being "rank" enough to retain its hold. Roach-fishers who like very fine wire hooks should remember that they can only have an amount of barb in proportion to the thickness of wire in the hook. After the wires are barbed, they are filed at 
the points, and in the case of "best" hooks are filed taper at the other or shank end; this is to give them a neater appearance when whipped to the gut or gimp. They then go into another department, where they receive their shape, and make their first appearance as hooks; and as there is a "pattern" to be formed for every shape, size, and description on which the wire is bent, my readers can imagine that there must be some little amount of brain-work required even in making such a common thing as a fish-hook. So far, all goes well, and our hook has received the desired shape: it now has to be hardened. This is done in trays in a furnace. When the hooks are "white hot," they are slid into a bath of oil to cool. They are now, of course, perfectly brittle, and before being tempered have to be cleaned and brightened. This is done by machinery, and they are then ready for the most delicate operation of the whole business, namely, the "tempering." There, again, as in the case of a too deeply cut barb, if the hook is not sufficiently tempered, off goes the point, directly a bone is struck; it may be only the point, although a break generally occurs where the barb is cut in; but if a fish is missed, the angler should always examine the hook at once, as if the fine point is gone, only a rough blunt point is left, and with this he must be extremely lucky if he catches anything at all. It is 
a good plan to have a small needle-file in the tackle-case, as very often a touch or two with this will repair the damage. But then, again, a hook may be over-tempered,-that is, too much of the hardening is taken out,-and than the hook becomes a perfect nuisance; all the spring is gone, and the first time a fish is struck out goes your hook "straight," and away goes your fish to inform his friends or write to his own special paper about the wonderful electric worm or fly that gave a marvellous kick directly he touched it. It is of no use to bend that hook back to its shape : take it off, and try the next before joining to your line. The tempering is performed in a fine sand-bath over a branch of the furnace, and it is really wonderful how very few mistakes occur, considering the immense number of hooks that pass through the hands of the "temperer." The instant that this important functionary considers they have arrived at the proper stage, they are shot into a sieve to separate them from the sand, and then are turned out on a table to cool. The hooks are now fit for packing, having received their blue shade in the tempering; in the case of "Limerick" and other hooks which are usually japanned, this is done after the tempering process. A large quantity are placed in a species of metal basin, and being warmed gently, a very small portion of black japan is poured on them, and they are 
quickly manipulated with a pair of forks, which causes them to be effectually varnished without allowing the japan to become "clotty." It is evident that, given good steel wire, everything depends on the temperer; very few indeed there are really first-rate in this department, which requires good judgment, and knowledge of what is required for the finest wire used in the manufacture of midge-flies and the coarse material worked up for sea-hooks. But "good" wire must be used, and that of a size in proportion to the size of the hook; not too stout, or the hook is too heavy, and will require too hard a strike to cause it to penetrate; and on the other hand, if too fine, and the wire is good, when a fish is struck the hook springs sufficiently to allow the fish to come unhooked, and then the hook returns to its original shape, whilst you puzzle your brains to account for the loss, till it has sprung once too often, and breaks off at the "bend."

The shapes mostly used in Pike-fishing are the round, the sneck, and the lip.

The lip-hook, as its name denotes, is principally used, in spinning-tackle, to close the mouth of the bait, which is effectually accomplished by the sharp angle. This is a very useful shape in sundry other portions of Jacktackle for attaching the bait in various ways; but the point is too rank for hooking a fish; and as from their position they are more 


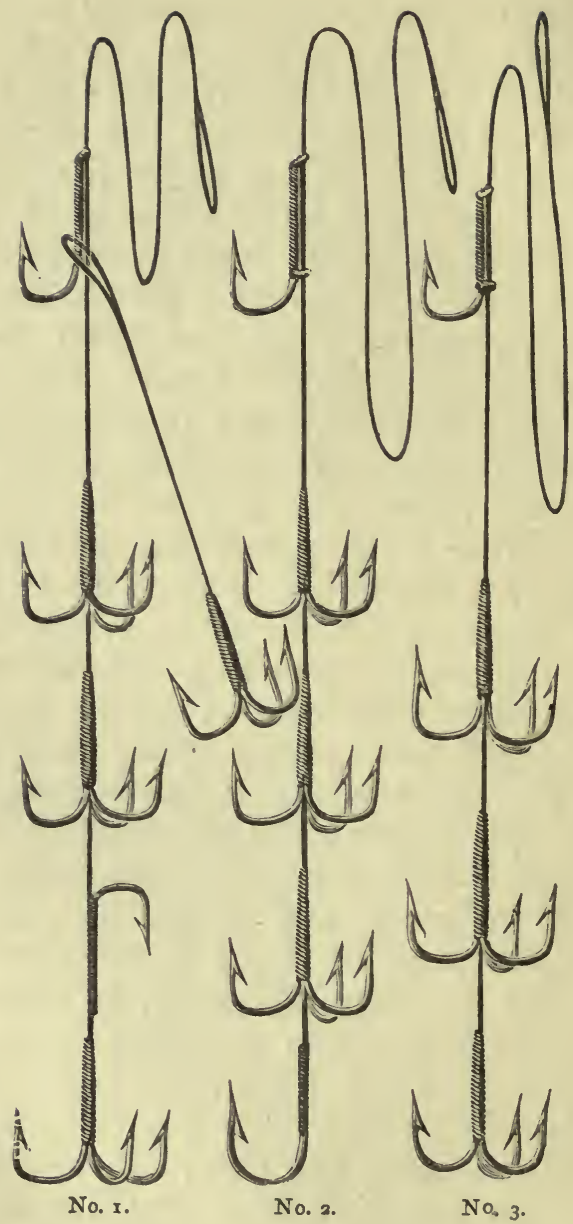


visible on the flight, so should they be rather small than large. The hooks intended for catching should be either sneck or round, whether as single hooks, or brazed together in the form of triangles.

I have sometimes found in spinning that I have missed a good fish through the Jack coming short at the bait. No. I is intended to remedy this. It has an extra triangle, mounted on gimp, having a small loop, which is passed down the gimp of the flight you are going to use, before it is fastened to the trace and hangs upon the lip-hook. One hook of this short triangle may be inserted in the other side of the bait, which, when using the first flight mentioned, would be exposed without hooks; and as Jack always take the bait across, this extra triangle will effectually prevent them tearing the bait off without being themselves hooked, as I have sometimes found them do when fishing without it. I used these fly triangles over twenty years since, and am persuaded that if they were more generally used, fewer fish would be missed with the spinningbait. They were sketched in my first edition of 1859 , and appear to have been appreciated. Nos. 2 and 3 are other varieties, the tail being curved by the end hook, as in No. I.

No. 4 is a different style of spinning-tackle : the whole of the weight being concealed in the bait, none is therefore required on the trace. It is used with a baiting-needle, thus: 


\section{P the needle, to which is attached the loop of the gimp, being in- serted in the vent of the bait, push it through, and drawing it out at the mouth, bring the triangle close up to the vent, and insert the loose hook in the tail, so as to curve it; take off the needle, and, draw- ing the lead on to the gimp, force it into the mouth of the bait, which is now ready for use.}

No. 5 is another excellent tackle, known as the "Waterwitch" or "Chapman" spinner; like the last, the whole of the weight lies in the head of the bait, the revolving motion being given to it by the pectoral fins at the head. To use it, the spear, having on it the lead, is pushed down the throat of the bait, so that only the pectoral fins are left projecting on either side of the mouth; the triangles at the sides may either be left loose or one hook of each may be inserted in the bait; this last will be the safer way if there are many weeds about. 


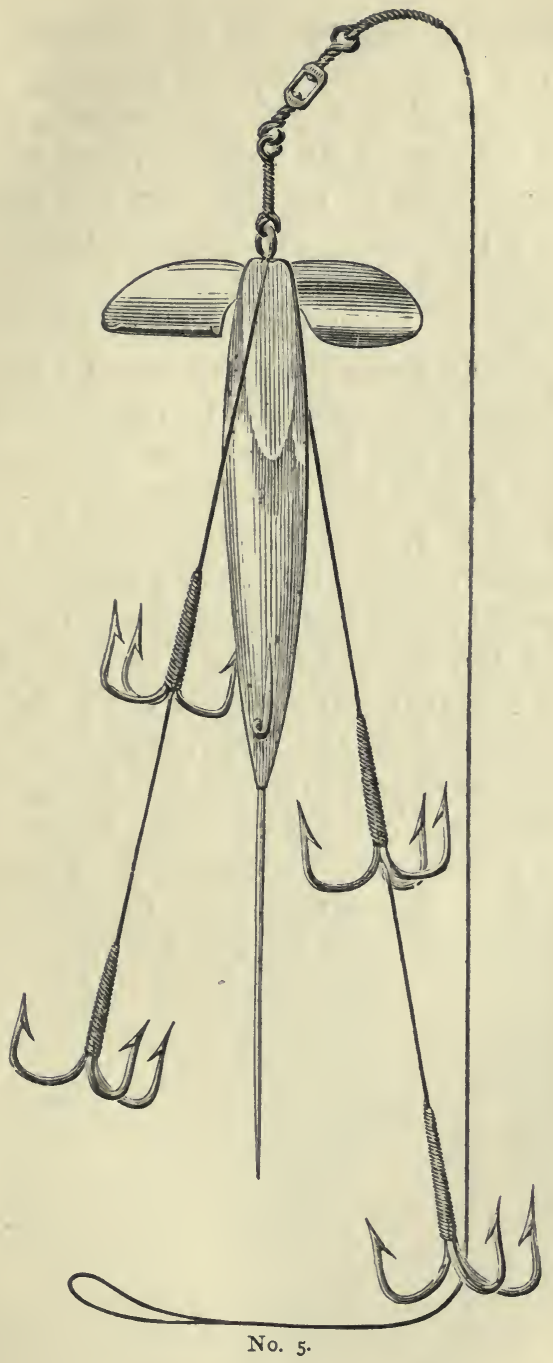


A different description of spinning tackle, but on the first principle of curving the tail, is the "Pennell," a drawing of which, in miniature, will be found at page I 3 , and which will explain the style of tackle, also the manner of putting on the bait. An improvement on this is the "Francis," which I think is a decidedly better plan of mounting, as the side-triangle stands well out from the fish; but I cannot help thinking that a fly-triangle to reach to the edge of the gills on the reverse side will be a great addition. No. 6 will illustrate this. No. 7 is similar to No. 3, and is much used in the midland counties. The lip-hook goes through the lips as usual; the first triangle is fixed at the shoulder; the second triangle is hooked in just behind the dorsal fin, so as to draw the bait up and give a crook to the body, which is thus bent in the middle instead of the tail being curved; the end triangle is allowed to fly loose. I have used this tackle very successfully in lakes.

No. 8 is a Trout spinning flight which will be found described in Chapter XI. 


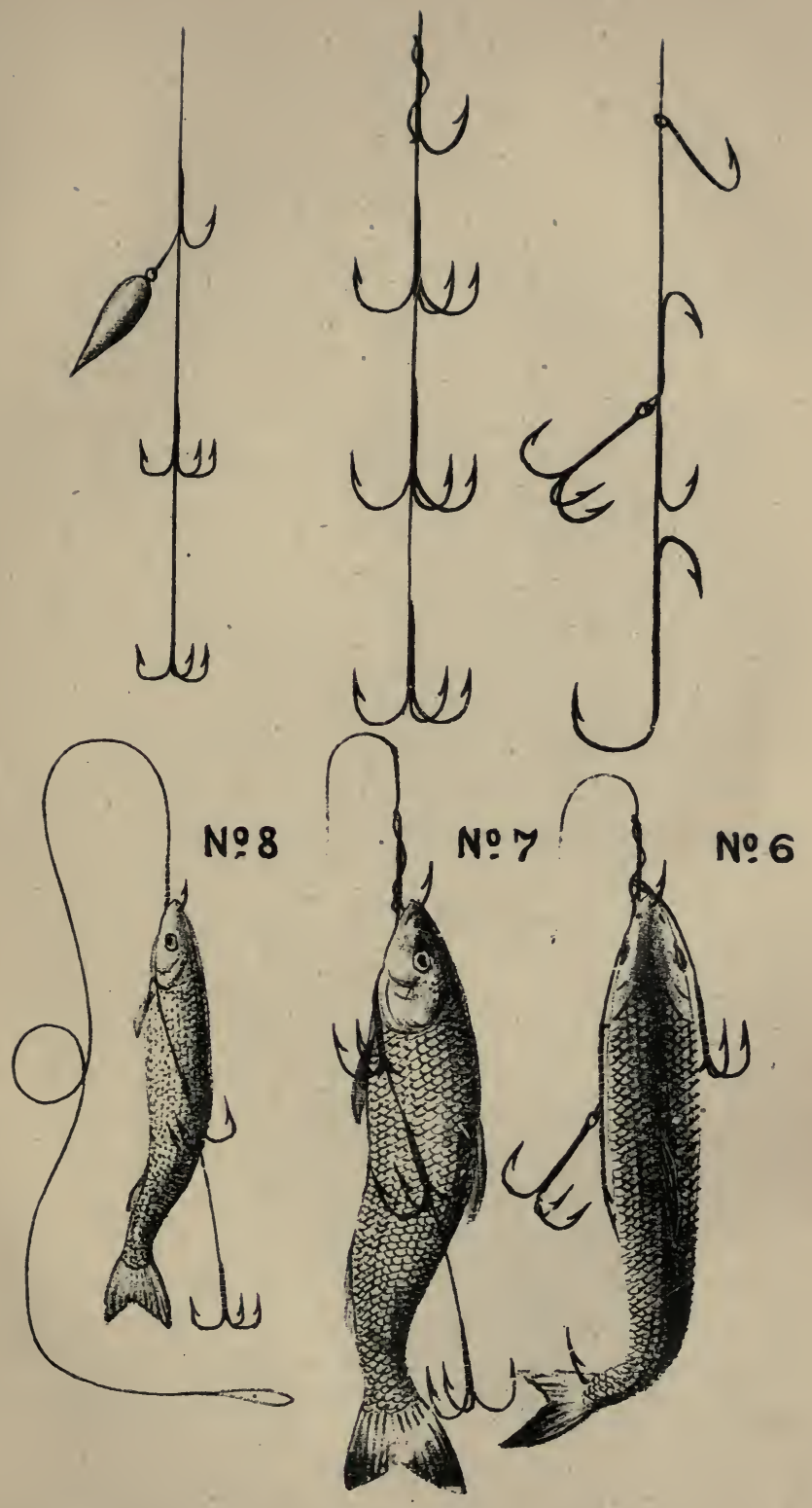



CHAPTER III.

ARTIFICIAL BAITS-CASE FOR SPINNING TACKLE, ETC.-FISH BAG-LANDING NET AND GAFF HUOK.

WE next come to artificial baits, of which there are a great variety. On this subject there has been a great deal said both pro and con, the majority of writers going against them principally because they never caught anything with them; they say that they are not so good as the natural bait-that they soon wear out-that they won't spin-and that it is derogatory to the character of a sportsman to use them. The first objection I believe arises through their never having fished with them, through want of faith, for the angler should bear in mind that, though patience is a virtue, faith must be added. As regards not being so good as the real bait, I can only say from my own experience that I have taken fish with them when I could not tempt them with the natural bait. The objection on the ground of not spinning is more correct, as regards some of the pseudo spinning-baits; those, however, having the pectoral fins may be relied on as being good spinners, always provided the fins are large enough for the purpose, without being too large, as I have sometimes seen the fins cut so small, through 
a false regard to neatness, that there really was not enough left of them to give the bait, together with the hooks, the necessary revolving motion. As regards the objection of not being sportsmanlike, I should hardly consider it worth answering but for the fact of some writers advancing it who really ought to know better; for what real objection can there be to using a bait which, in the first place, makes a considerably brighter appearance in the water than a natural bait would do after a few throws, and which will last for two or three seasons, or even longer, with care? And I have used one of the pectoral baits for two seasons with the greatest success, and should have used the same one a third season, but unluckily lost it through getting foul. It also saves the trouble of carrying a kettle of baits to the water-side, for although many carry a few baits in a box in their pocket, still they must become stiff by the time they arrive at their destination; and I think, in common with some of the best Thames spinners (who are allowed to be the best spinners in the world), that a natural bait does not spin so well after it has become stiff as when it is only just dead.

The artificial baits most in use, and which I consider the best, are the pectoral-fin baits, of which there are several sizes; with the smaller of these I have occasionally taken a good Trout while fishing for Jack early in the season. The 


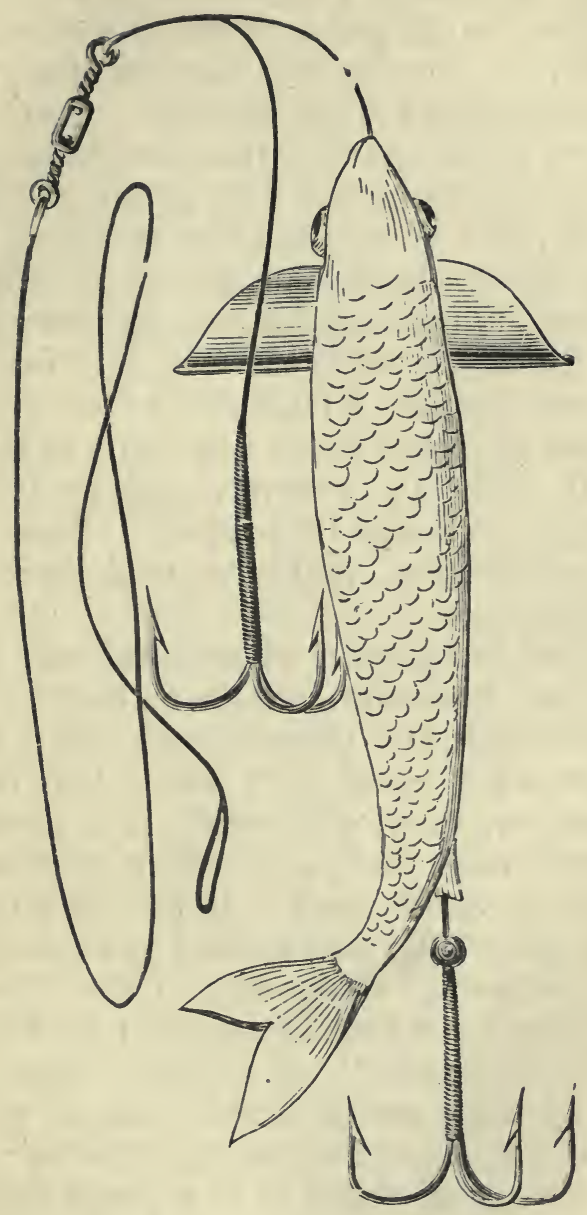


style of mounting I prefer is this: The bait runs loose on the gimp, to which is attached the tail triangle, thereby spinning on the gimp as well as spinning with the swivels. On the gimp at the end of the shank of the triangle is fastened a bead, to prevent the bait slipping down on the hook, and to secure a free spinning action. To the swivel above, and about an inch and a half from the nose of the bait, is fastened by a piece of gimp of sufficient length to reach half way down the fish, a triangle to fly loose round it, so that any Jack of an inquiring mind as to artificial baits in general, and pectorals in particular, will find it proved, I hope to his entire satisfaction, that one trial thereof will be sufficient.

Another description of pectoral bait is that called the Phantom, which is made of silk, silvered or gilt, and painted, and, being hollow, collapses when seized by a fish. This bait is a first-rate invention, with which it is almost impossible to miss Jack, as it offers no resistance whatever to their teeth. It has one triangle hook on each side, and a third at the tail.

The following sketches are the sizes for Perch, larger sizes being required for Pike.

The "Cleopatra" is a metal bait, made hollow in the form of a fish, but in separate sections, which are hinged together by pins so as to make it flexible; it is a great improvement on the old form of metal bait, and I think will be found a wonderful killer, especially 
if the water is at all coloured. With a similar bait, but not jointed, I caught an eight and

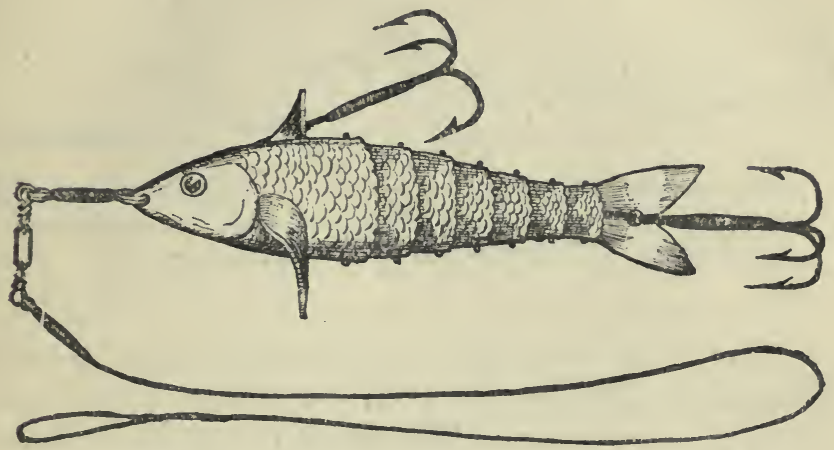

a quarter pounds Pike, in September 1877 , at Datchet. I saw him feeding under some bushes: he refused the natural spinning-bait, but with the artificial I caught him at the third throw. The Fishing Gazette says of this bait, "We think the name is an excellent one, not because Cleopatra's Needle is in everybody's mouth, at this moment, so suggestive of what might be in a fish's, but because we have the impression from past reading that the Egyptian charmer was a bright article (in more senses than one), was lithe of body, and 'very taking' in her ways."

The "Gregory" is another pattern of a metal bait, but made rigid; and revolving on a wire, which runs through it from end to end. The shape of the bait and manner of mounting will 
be obvious from the sketch, the two flying triangles revolving with the bait.

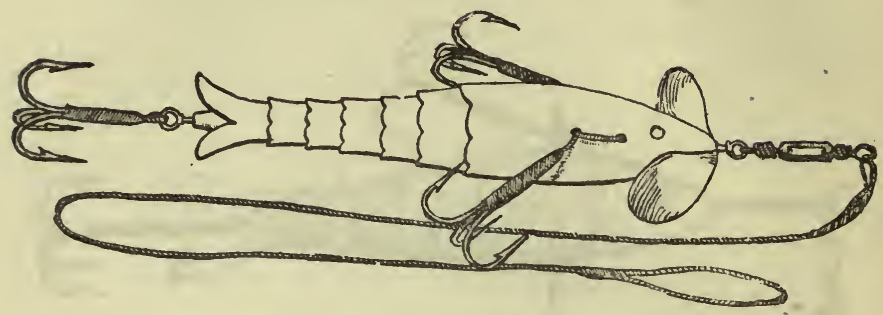

Last, but not least, come the Otters and Spoons. The former spin on a wire by means of a pair of fans. The Spoons are in various forms, either plain in shape or with the addition of a tassel of bright scarlet wool: these latter are very attractive, and I have found them kill very well.

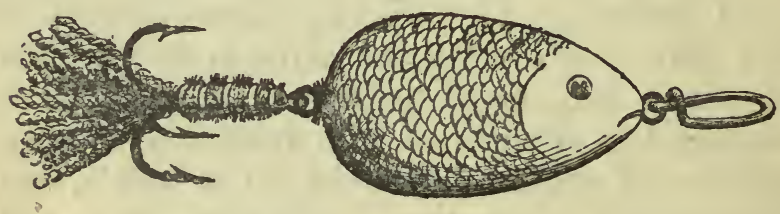

To hold the flights and traces the spinner should be provided with a proper tin case about six or seven inches long by about three or four inches wide, and deep in proportion, with divisions inside, for the purpose of keeping the flights separate as much as possible. The cover of the one I use is made in the form 
of a box to hold the traces and extra weights, such as dip-leads or large shots.

Some anglers use a round box for the purpose, with one or two trays in it, but this I hardly think so good as the former shape with divisions, as the flights being coiled round and all together, are sure to get in a knot when shaken, as they must be when the box is carried in the pocket, and I think there is nothing so bad to disentangle, at the waterside, as half a dozen or so of flights of hooks well knotted together.

The artificial baits had better be carried separately in another tin box.

As a final portion of the Spinner's equipment, he will require a large fish-bag or haversack, having a division in it, so as to form two pockets, the outer one for fish, and the inner one for tackle. These fish-bags I think considerably more convenient than the pannier, in which tackle and fish are mixed together, and which, if you have one large enough to hold a tolerable-sized Pike or two, seems to be always getting in the way; while the fish-bag, fitting close to the side, will hold considerably more, and when not in use can be rolled up and carried in the pocket.

As a matter of course the angler will be provided with a large landing-net or gaff-hook, which will be found an indispensable article to a Jack-fisher. 


\section{CHAPTER IV.}

INSTRUCTIONS IN SPINNING-THROWING THE BAIT —STRIKING, PLAYING, AND LANDING THE FISH.

If you use the natural fish, be careful how you bait your spinning tackle with it. The difficulty attached to putting on a bait properly often deters persons from spinning who would otherwise do so, as it is not a very easy operation for a beginner; but practice, and a careful attention to the preceding directions, will soon overcome these little difficulties.

To throw the spinning-bait, draw from your winch as much line as you require to reach the distance you intend to throw it; about fifteen or sixteen yards will be sufficient to commence with; when you can get that length of line out well, then increase it a yard or two at a time. A first-rate spinner can throw from forty to fifty yards of line, or even more; but on no account have out more line than you can conveniently manage. The extra line will only be in your way, and if you are fishing from the bank will be sure to catch up pieces of twigs and grass. Having unwound suffcient line from your winch, let it fall in loose coils by your foot on your left side, and holding the rod firm in your right hand about eighteen inches up the butt (to the socket of which should be fastened a large button), 
which should be kept tight to the hip, draw the line in with your left hand till the bait hangs about five or six feet from the top of the rod; bring the rod round to the right, and throw the bait sharply to the left, or vice versâ, as occasion may require, at the same time letting free the line in your left hand. The bait will then be carried out to the full extent of the line, the coiled portion running freely through the rings.

The bait having entered the water, spin it either across or against the stream ; in fact, in any direction that the nature of the place may render most convenient. Generally speaking, it is not of vital importance which way you spin your bait, so that you do it well. Observe to keep your rod steady with the point about a foot from the surface of the water, holding it so that the top may keep a slight strain upon the line, which should not be drawn in too fast at each backward motion of the left hand. When weeds are found within six or eight inches of the surface, the bait should be skimmed, as it were, nearly along the top of the water. This may be done by having a light bait, fewer shot, and keeping the top of the rod well elevated. Spin in a steady manner, just sufficiently fast to make your bait revolve attractively at about half the depth of the water without fouling weeds, but not so fast as to make its speed greater than that of the fish pursuing it. The revolving or spinning 
motion communicated to your bait as you draw it towards you, undoubtedly makes it exceedingly attractive to fish of prey. It then seems to fly madly for its life, although it possesses none. Predacious animals of all sorts rush with might and main after the prey that flees with the most timid fleetness from them. Make it therefore no difficult task for the Jack to overtake your bait and seize it with facility.

A lesson in spinning from a first-rate Thames puntman will do more good than reading all the books ever written on the subject.

In spinning, strike with a short and moderately strong jerk of the wrist, as soon as the bait is taken, although the fish will very often hook himself.

We will suppose that you have now hooked your fish, which, be it Pike, Jack, Perch, or any other, will, if it be of any size, require careful handling. Do not be in a hurry to land him. More fish are lost by the nervous feeling which shoots through the young angler when he feels the first rush of a Pike than by any other course whatever. Keep the point of your rod well raised and your line taut; if he makes for a bed of weeds and pulls hard, give him line, but still try to turn him by holding your rod the contrary way, and endeavour to lead him back to the place from whence he started. Now he strikes off again; let him go; now wind him in again, but do not distress your 
line by keeping it too tight on the fish. $\mathrm{He}$ now makes shorter journeys, and seems inclined to come to shore; hold him a little tighter, and feel if he will allow you to raise and show him, but be collected and careful. If fishing from the shore, try to lead him to the nearest opening in the rushes. Keep your line free, for he will possibly for a few moments be more violent than ever, as if he were determined to break the strongest tackle. Give him a few turns more, and he will be quiet enough. Now draw him again in-shore, making it a rule to float him on his side, and keeping the head a little raised above the surface of the water, so that the nose or gills may not hang to, or catch hold of, weeds, etc., while you are thus engaged in landing your prize ; for sometimes you cannot avoid drawing your fish over or among the weeds; and if not careful to raise the head, a Pike will often touch and get entangled in this way, and before it can be got clear will recover from its exhaustion, and occasion some amount of trouble and hazard before it can be again subdued. If you have a friend with you with a landing-net or gaff-hook, your fish is easily landed; but if you are alone, and without a gaff, then draw him as close as possible, and keeping the line tight, grasp the Pike behind the gills, and throw him up a few yards on the grass.

Although it is sometimes necessary to play 
a Pike till tired, especially if the angler is alone and the fish a large one, yet never play him longer than absolutely necessary, as the Pike when taken with the spinning-bait, being hooked in or about the mouth, the hooks will in time come out or break away, especially if they have only entered a skinny part. Therefore, always land your fish as soon as possible.

It is supposed by some that large Pike are less frequently caught by spinning than by fishing with the live-bait. If the supposition be true, it is either because the latter is more often used than the spinning-bait in places where large Pike lie, or because it can often be used in parts between the weeds where there is no space to work the spinning-bait, and not because the live-bait is the better on the whole.

\section{CHAPTER V.}

LIVE-BAIT FISHING-THE ROD, WINCH, AND LINEFLOAT-TRACE-LIVE-BAIT HOOKS, AND HOW TO BAIT THEM - THE PATERNOSTER-BAITS AND KETTLE-IMPROVED BAIT-CAN.

FISHING for Jack with a live-bait and a cork float attached to the line is certainly the most popular, as it is also undoubtedly the easiest. But I do not consider it so successful a method 
generally as spinning; for to take the whole season for Pike-fishing, I believe that he who confines himself to spinning will kill considerably more than he who for the whole season fishes only with the live-bait. The little labour or exertion, however, required to take Pike by this style of fishing is doubtless the cause of many preferring it, as it allows them frequent opportunities of resting when they reach a clear, quiet place, either in ponds or rivers, when they have the pleasure of watching their float work up and down through the live-bait sailing to and fro, which certainly has the effect of attracting the attention of the Jack to it; but they often drop the bait when not well on the feed, or blow it out of their mouth again, from the hook or gimp touching them when shifting the bait to pouch it. This frequently happens when using the single hook with the bait hooked through the back fin; which is my principal reason for preferring the double hook, lying on the side of the fish, for the Jack always pouching it head-first, it is almost impossible for him to feel the hook till he has it well down.

The rod of mottled bamboo, recommended for spinning, will also do well for live-baiting. The spare tops being of different lengths, use the shorter one, which will entirely alter the character of the rod, making it about a foot shorter, and stiffer in proportion.

The winch I consider the best for live- 
baiting is the one made of hard wood, which, besides being light, has the great advantage of allowing the line to run off freely when you have a bite, which in Jack-fishing is termed a run, and the rod is lying on the ground. Otherwise, if you are using a brass winch, it would be necessary to leave a few yards of line loose on the ground, so as to allow the Jack, after taking the bait, to run without hindrance to the hole or haunt where he feeds. Thus much for the wooden winches, which, however I may dislike them for spinning, I still think decidedly the best for live-baiting.

I prefer rather a fine line for this style of fishing, unless in a water where the Pike run very large, as a stout line, after soaking a short time, is sure to sink and get entangled with the bait, while the fine line will float for a considerable time (especially if it be rubbed once or twice in the course of the season with strong palm oil), besides having the advantage of cutting through the weeds when a Jack takes a fancy to run into a bed of them for the purpose of pouching the bait. The line should be from fifty to eighty yards in length, for although many say that they do not see the use of having so long a line, yet when a Jack-line is in constant use and is well soaked in the water, with now and then the strain of a twelve or fifteen pound Pike on it, you will find it necessary tc break off a yard or two occasionally from the working end to keep it 
in good order, although the line may be well dried before putting away.

A fisherman who, from a false notion of economy, merely sports his thirty yards or so of line, and breaks off now and then a yard or two when the end has got tender from constant wear, or has it broken off for him by a good fish, finds that he has hardly enough left to afford a Pike a fair run, especially in a wide stream. Then to make his remaining line serviceable he splices a piece on, and the first time he runs a heavy fish, the chances are ten to one that the splice will somehow or other knot up or catch in the rings, and before it is clear again, he makes the discovery that the float has come up, and the fish, as soon as he felt the check, has left the bait, most likely bitten in half, or so crushed as to be useless. Therefore, always have a line long enough at first, of the best plaited silk, and prepared with waterproof dressing.

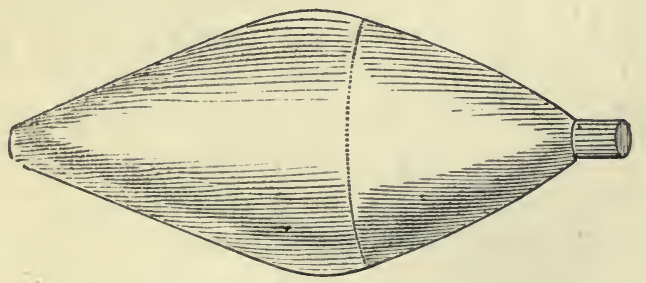

Proceeding in the order in which the tackle would be put together, we come to the Livebait Float. I prefer one of this shape, with a 
hole entirely through it. Having run your line through it, push in a small plug, and only allow about a quarter of an inch (or even less) to appear above the float. By this con-

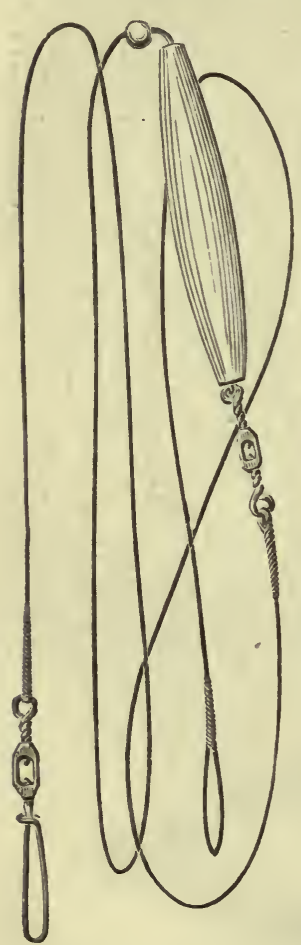
trivance the float is made considerably shorter than the old-fashioned ones, which is of some consequence in livebaiting; because when a Jack has taken the bait and turns among weeds to pouch it, a long float often gets entangled therein, and checks or alarms the Jack, when he drops the bait instead of pouching it. A float sufficiently large to carry a lead of the size given on the annexed trace, and a bait of about six inches in length, will be found, generally speaking, the most useful.

If fishing weedy water, it will be found a good plan to fix on the running-line, above the float, two or three small round cork balls about half an inch in diameter: these are termed "pilot-floats," and are very useful for keeping the line from sinking in the weeds : they should be fixed two or three feet apart.

The next thing required is the Trace, which is fastened to the line with a knot like the one 
for spinning, and of moderate-sized yellow gimp, having two swivels; one in the middle, below which comes the dip-lead, which is kept in its position by means of a large shot; and another swivel, which should be a hook one, at the lower end.

The hooks used in live-bait fishing are of two sorts, single and double.

The single hook, which should be about this size, may be used either by hooking the bait through the side of the lips, or by passing it under the back fin, and bringing it out on the other side, being careful, however, not to insert it too deep, so as to injure the bone,

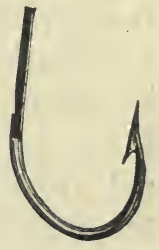
for if it does the bait cannot swim strong, and will soon die.

The double hook, which I consider the best of the two, should be used in proportion to the size of the bait; the pointed half should be slightly bent up from the shank, so that when baited the points may stand out a little from the bait fish.

To use this hook, take a baiting

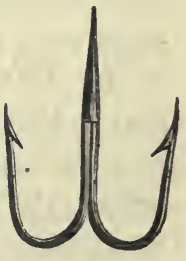
needle, and placing the loop of the gimp on the hook at the end of the needle, enter the point of it under the skin of the bait on the shoulder, and just behind the gills, guiding it carefully along, and bringing it out near the back at the end of the back fin, draw the gimp, from 
which you now take the needle, till the bend of the double hook is brought to the place where the needle entered, when the bait will appear as in the sketch-(see next page).

The loop is then fastened on the hook-swivel at the end of the trace, and the bait is ready for use.

Observe that the gimp and shank of the hooks lay under the skin only of the bait; be careful, therefore, in passing the baiting-needle beneath the skin to do it cautiously, so as not to wound the flesh, or remove the scales unnecessarily; the bait then appears to feel very little inconvenience from the operation, and will swim nearly as strong in the water with the hooks as without.

In fishing weedy places, always clear the hooks from any small weeds that may catch to them when you draw it out of the water, for although the Pike is a voracious feeder, still he will often refuse the bait if there is the slightest particle of weed hanging to it.

The Paternoster is used properly without a float, although some prefer it with; in length it is about a yard and a half, of yellow gimp, with a Paternoster lead at the bottom fastened by a loop. On it are looped three hooks, size about No. I, the bottom one six or seven inches above the lead, the next about a foot above the bottom hook, and the next a foot above that. A sketch is given at page 42 . To use the Paternoster, fasten the loop to the running line as usual, no trace being required; the baits, 

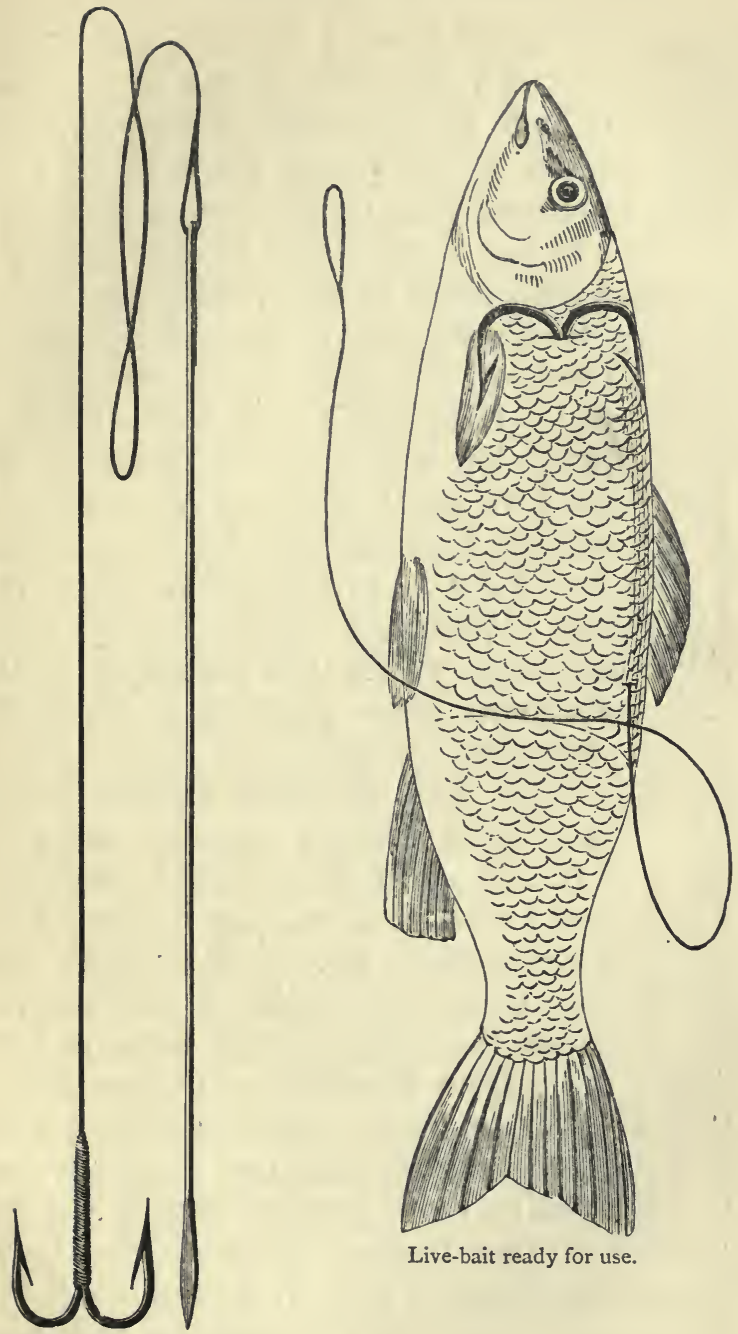

Live-bait ready for use.

Double-hook and Baiting-needle. 
either gudgeons or dace, are hooked through the side of the lips. Commence by dropping in near the side, or if there is one place more likely than another by all means try it first. Let the Paternoster sink till the lead touches the bottom, keeping the line rather tight to it. After a few minutes, if you have no success, work it towards you by raising the point of the rod and drawing in a yard or so of line slowly, still touching the bottom with the lead. When you have a run, slacken your line, and give him a minute or two before

$\rightarrow$ striking, which you should do rather sharply, then play and land him secundum artem.

This is a first-rate tackle for trying holes among weeds, when the live-bait with float would inevitably get entangled, as the hooks on the Paternoster allow the baits only about six inches play round the line, while the lead on the bottom keeps them from running into the weeds.

When made as described, with the three hooks, the Paternoster is usually baited with small gudgeons,

$\rightarrow$ or other fish of three or four inches in length; but with ordinary Pike baits, such as Thames or Colne dace, 
two of the hooks are removed, and one only is used; the gimp of this hook is then about a foot in length; whilst when three hooks are used, they should be on gimp of only five or six inches long, or they will become entangled with each other.

The best baits for live-bait fishing are dace or very small chub; some prefer a lively roach, but the baits that live the longest, and are therefore the best for a long journey, are Thames gudgeons, as they are a strong hardy fish, and will bear more rough usage than any other bait. If you are alone, a dozen or a dozen and a half will generally be sufficient; they should average about five inches and a half in length.

The last article required is the kettle for carrying the live-baits. This should be a full-sized one, made either of zinc or tin japanned, brown outside and white inside. The former metal I think wears the longest, but in the japanned tin kettle you see the baits better, and can therefore select one sooner than you can from the other. If going a long distance, change the water as often as convenient, and when at the river-side it will be better, when not in use, to keep the kettle in the water out of the sun, (tying one end of a cord to the handle and the other end to a peg, which you can stick in the ground,) and let it remain till you move or require a fresh bait. 
The "improved" bait-can is shown in the sketch, and is thus described in the Fishing Gazette of 28th Sept., I877: "This attracted our attention at the Piscatorial Exhibition

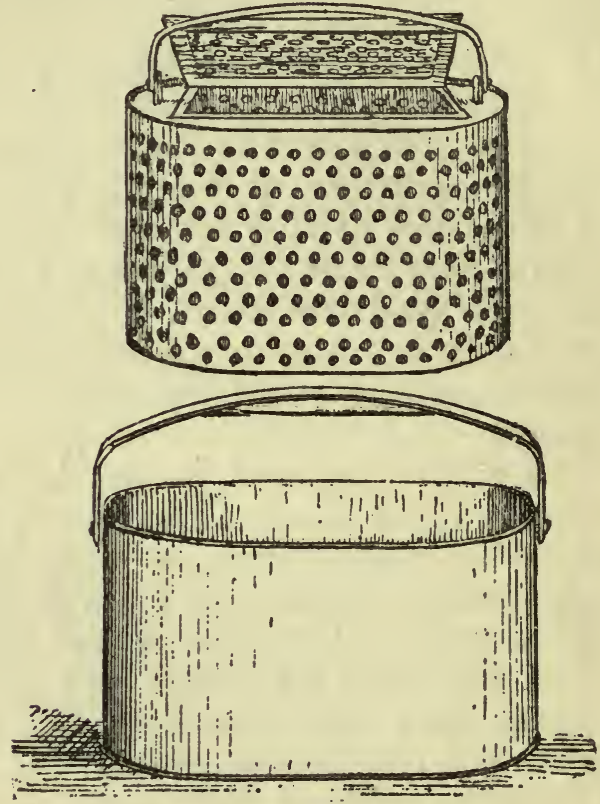

as being of practical aspect. The arrangement simply consists of a fish-holder made of perforated zinc, which fits accurately into an oval water-can, as shown in the above figure. It will at once be seen how readily the live-bait placed in the inner vessel can - be drained from stale water-placed safely in 
a running stream if opportunity presents-or be replaced in the outer can after a change of water."

\section{CHAPTER VI.}

THE BANK RUNNER, TRIMMER, ETC.

Some anglers, while fishing for Jack with a rod and line, lay in a bank-runner; this is stuck firmly in the bank, the upright being sharpened to a point for the purpose, the reel on the top having on it twenty yards or so of strong water-cord; on it is placed a live-bait float, or bung large enough to carry the bullet which keeps the bait down, and which is fixed between two shots a foot from the end of the line, to which is fastened a strong hook swivel; this is now ready to receive the baited hook, which may either be a single hook inserted through the lips of the bait, or a double hook threadled under the skin, as mentioned before. The bank-runner, without the float and baited with a dead fish or a large lob-worm, is much used for taking Eels.

Many large Pike are taken in ponds by using a trimmer, but this is an unsportsmanlike way of fishing, and is only mentioned now because it is sometimes used. The trimmer 
is a round flat piece of cork, four or five inches in diameter and about an inch thick; round the edge is cut a groove, sufficiently deep to hold the cord-line, which is about five yards in length at most; through the centre of the flat side is fixed a peg, with a notch in it for the line. to hang in; one side of the cork is painted red and the other side white; the line is fitted with bullet and swivel, the same as the bank-runner, the trimmer itself acting as float; the hook is baited the same as in livebait fishing. When the trimmer is started in the water, the white side, from which the notched peg should project about four inches, floats uppermost; the line is then placed in the notch, allowing the bait to hang about four or five feet below the trimmer, but this should be regulated according to the general depth of the water.

When a Jack seizes the bait, he pulls the trimmer over, and it then floats red side up, showing that there is a fish on. The trimmer may now be got out, either with the assistance of a boat or by throwing a drag over it, if the distance is not too great.

In some parts of the country a large bladder is used as a trimmer, the line being tied securely to the neck, and a full-sized dace or roach being used for the bait; the line in this case should not exceed two yards.

Ducks and geese are sometimes used instead of the bladder, for the same purpose, the line 
being tied round the body, and strong hooks and a large bait used.

All these ways, however, are unworthy of the true angler, who exercises his skill and art more for amusement than profit, and should only use the rod and line.

\section{CHAPTER VII.}

WHEN, AND HOW, TO FISH WITH LIVE-BAIT FOR PIKE-STRIKING AND LANDING THE FISHPIKE-GAG.

THE best time for live-bait fishing is when the heavy weeds are rotten, and are, together with rushes and sedges, daily wasting, and being washed away by floods, etc., which generally commence about November. From October till March, Pike will take a live-bait more freely than at any other time of the year.

Fix the float at a proper distance from the live-bait, which as a general rule should not be less than three feet, but is sometimes required considerably deeper; for, to fish a hole of ten feet in depth, and tolerably clear of weeds at bottom, I should certainly not fish less than seven feet deep; that is, I should have the float that distance from the live-bait.

Commence by casting in your bait gently 
near the shore first, always standing as far from the water as possible without losing sight of the float; if after a short time you do not have a run, advance a little nearer, and make another cast further in the water, and to the right or left. Try all the bays, bends, and still parts of the river in succession, and ponds, pools, etc. ; also near, or in the open places, among beds of candock weeds, sedges, rushes, and in retired corners. Eddies at the sides of weirs are good places for large fish; and here, besides Pike, you have the chance of catching large Perch, which will readily take the live-bait. I have often taken them in such places of two pounds weight when live-baiting for Pike, and sometimes as high as three pounds and a half.

If the bait be lively, it will swim strongly about; if there should be a bed of weeds near, will generally make for it; and if left to itself, will there get entangled, which must be prevented by drawing it gently away; but not out of the water. When the live-bait becomes weak, which you will soon discover by the float not working much, draw it gently to and fro, (if it be hooked through the lips only,) which will often induce a Jack to seize it, fearing it is making its escape; though while the bait remains quiet, the Jack is seldom in a hurry about it, which proves the advantage of strong and lively baits over those that are weak and languid. 
When you take your bait out of the water to cast it in another place, be careful to draw it slowly and gradually to the surface for that purpose; for I have often found Pike and Jack, when not much on the feed, strike at the bait when it seemed to be escaping from them. Those who take out their line without attending to this rule, will often find Jack strike at the bait whe $\mathrm{n}$ it is being drawn out; and in their eagerness to seize it, sometimes throw themselves out of the water after it. I had this occur to me some time since whilst fishing in the Lea at Broxbourne. I had drawn my bait slowly to the surface, and it was entirely out of the water, when a small Pike, of about six pounds weight, sprang completely out of the water after it, but unfortunately missed it, although I instantly dropped the bait to him.

When a Pike seizes the live-bait, or, in other words, when you have a run, it is generally with violence, and the float is instantly drawn under water; watch the float as long as possible, and keep your winch and line clear, holding a yard or two of slack line in your left hand, so that nothing may stop or check the Jack when he has seized the bait and is making for his haunt to pouch it. If he runs rapidly, draw the line quickly from the winch with the left hand, so that he may not be impeded. When he has reached his haunt and lays still, allow him, in general, ten minutes to pouch; or if he is quiet, you may 
give him a minute or two longer, for you must remember that when a Jack has gorged the baited hook, he cannot possibly get it out again; but if you strike before he has done so, you risk pulling the bait from his mouth without the hook touching him; therefore, the only chance of losing Jack after they have taken the live-bait, is in not giving them time enough to pouch it, supposing them to be inclined to pouch; (as a general rule, when a Jack has pouched, the line slackens slightly). But if, when you have a run, the Jack or Pike moves some distance, and stops a minute or two, then moves off again, stops a few moments as before, and then a third time changes his quarters, you may expect that he will not pouch, but that he is either more on the play than on the feed; or, if it is a small fish with which you have a run, that there are larger Pike about the spot that prevent the one which has taken your bait from stopping, either for fear of the stronger one taking his prey from him, or, as is sometimes the case, the larger one seizing him.

When you have reason to suppose that a Jack is more for playing with the bait than feeding, and he has moved a third time, then wind up the line and strike smartly the contrary way to which the Jack is running, and you will probably hook him, in or about the mouth. But when you have a run, and the Jack or Pike after having taken the bait, and 
moved a certain distance, remains still for three or four minutes, then shakes or tugs the line and moves off rapidly, wind up the loose line and strike, but not with too much force, for you will find if a Jack has laid quiet for three or four minutes and then gets restless, that he has, generally, pouched the bait (which Jack will sometimes do directly they take it), and begins to feel the hooks. I have sometimes found on landing a Jack that he had got the hook completely down, but that the bait, which he had blown out again, was swimming a foot or more up the line; and with the same bait, which in a few instances has only had two or three teeth-marks on it, I have taken another Jack directly.

The voracity of the Pike is well known to be enormous. I know of two or three instances of Pike being choked through trying to swallow one slightly smaller than themselves. There is a case mentioned of a large Pike in a lake seizing a swan by the head while it was, according to custom, groping among the weeds. He got the head down, but the body was too large even for his capacious jaws. The carcases were found a few days afterwards on the shore: the Pike being unable to disgorge, was choked. To these torments of the finny tribe nothing comes amiss, from a duck to a leaden plummet. One was taken in the Lea some time since, while the angler was plumbing the depth in a Roach-swim : the Jack, 
weighing nearly two pounds, took the plummet and was safely landed, owing to the hook, which was rather a large roach-hook on fine gut, projecting from the side of the plummet.

On hooking your fish, act as directed in Chapter IV. Do not strain on him too hard; keep him as much as possible from running into beds of weeds and other dangerous places; and when bringing him to a convenient landing place, and he is almost in your hands, be prepared to allow for some heavy plunges. In this probable case act with coolness, and when it occurs let him have another turn or two in his own element, and when he becomes tractable land him as soon as possible, for although I never play a fish longer than I can help, yet when a good fish plays well, there really is no occasion to strain the tackle merely for the sake of landing him a minute or two sooner. I believe that many good Pike are lost through the anxiety of getting them on shore, and especially while they are having their last struggles, for then the angler should yield somewhat to the fish; but, on the contrary, the young practitioner generally redoubles his efforts to drag his prize on shore nolens volens, and not unfrequently, by using such improper force and holding his fish too hard, breaks his tackle and loses his fish.

Always make it a rule to bait your hook the last thing after you have got all complete as regards line, float, etc.; for the more lively 


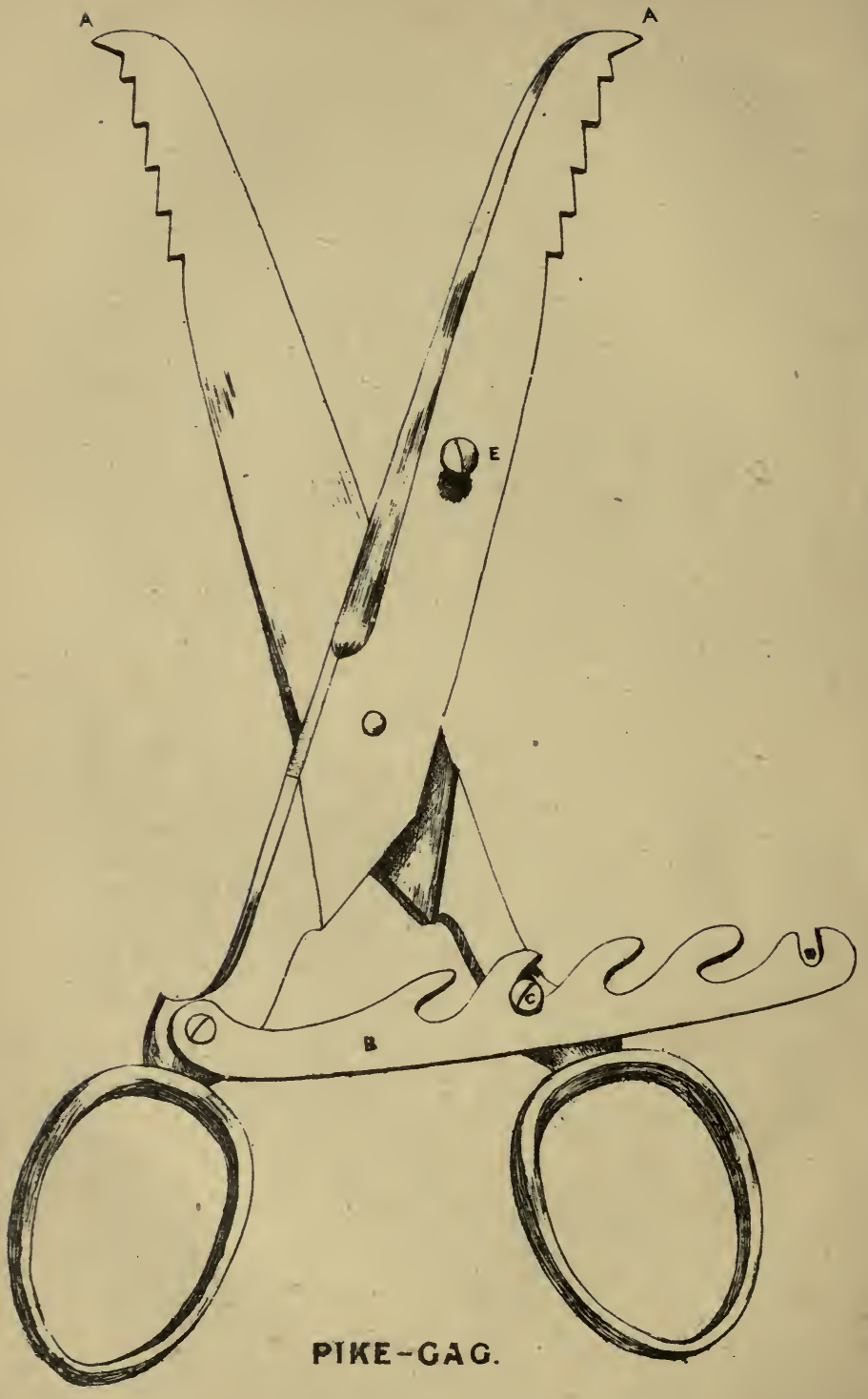


and strong the bait swims, the greater chance you have of a run, and the fish pouching instead of blowing it out, which is sometimes the case when they are not much on the feed, or the bait is not very lively or tempting.

And, lastly, remember when Jack-fishing, either with spinning, live-bait, trolling, or snap, in a place very likely for Pike to lay, not to leave after a throw or two only, but let the bait work the place well, especially if you have seen a good fish move there before, or if you have a run and the Jack leaves the bait. Try every foot of likely water well, and if not successful try again as you return.

A most useful implement in Pike-fishing is the Pike-gag, which I have found of great assistance when disengaging the hooks. It shuts up like a pair of scissors, and to use it, the points $\mathrm{A} \mathrm{A}$ in the sketch are inserted in the mouth of the Pike, which can be opened to the required extent by means of the bows, which fit on the finger and thumb. The gag is kept open by means of the steel extender B, the teeth of which are made to catch on the screw $C$, but when not in use this portion shuts up on one limb of the gag, the notch D fitting on the screw $\mathrm{E}$, and keeping it secure. The Pike-gag can also be used as scissors, being very strong, and made sharp for the purpose. 


\section{CHAPTER VIII.}

TROLLING-THE ROD, WINCH, LINE, AND TRACEGORGE-HOOK, AND HOW TO BAIT IT-WEEDHOOK-SPEAR-GORGE-GORGE-BAITS.

THIS was formerly considered the highest branch of the art of Jack-fishing, and is still considered so by some anglers, although not much practised in general,-live-bait fishing and spinning being decidedly the most popular, as well as the most successful. It takes its name of trolling from the troll or rolling motion communicated to the bait when in the water.

The rod, winch, and line used for trolling are the same as for spinning. The line should neither be less than sixty yards, nor too stout, as I consider that the finer the angler's tackle the greater chance there is of finding fish.

The trace used when fishing with the deadbait is of moderate-sized yellow gimp, with two or three swivels, and no lead, the whole of the weight being on the gorge-hook. Some troll entirely without swivels or trace, but it is evident that so doing is a decided impediment to the spinning or revolving of the bait, and, therefore, by all means use the trace; by using the hook-swivel at the end, the gorge hook can be readily disengaged. 
We now come to the gorge-hook, which is of the following shape:

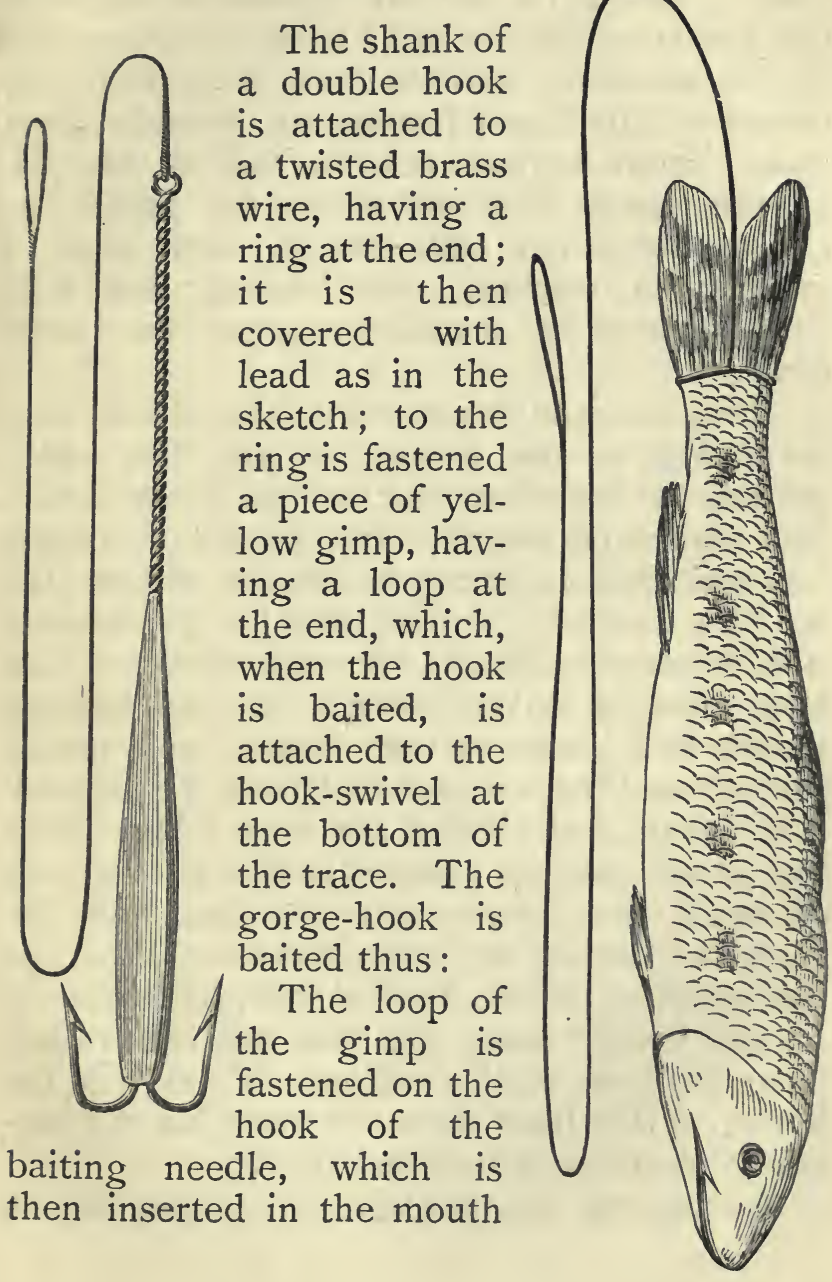


of the bait and run through, bringing the point out in the centre of the fork of the tail. The gimp is then drawn through till the bends of the hooks fit close on either side of the mouth of the bait, as in the sketch, the points of the hooks having an upward direction. Some anglers tie the tail of the bait to the gimp with white silk or thread, so as to keep the bait steady, and also to prevent it tearing, and having the tailpart injured by catching against the weeds, etc.

The size and length of the hook will vary according to the length of the bait, which should be from four and a half to five and a half inches in length; this should, of course, be regulated according to the size of the Jack or Pike likely to be met with in the water in which you are fishing; the wire should be just long enough to keep within the bait, and the points and barbs of the double hook should project as little as possible from the sides of the mouth, but should lay very close; for if the points project, besides catching every bit of weed that comes near the bait, they are very likely to be felt by the Jack when changing the position of the bait in order to pouch it. In the former case, the bait will most likely have half its scales rubbed off; and in the latter, if the Jack feels the hook, he will certainly drop the bait immediately.

As regards the question of cutting off the 
fins of the bait, I think it is decidedly the best to cut them all close, although some anglers leave a pectoral fin on one side and a ventral fin on the other, cutting off all the rest; but the reader will find that with the fins off the bait revolves more freely in the water, when sinking or being drawn up, than when the fins are left on ; the bait will also last much longer without them, as they often catch or hang to weeds, and when this happens the bait is generally torn so as to be almost useless.

This is of some consequence to the angler who is short of baits, and is at a distance from any place where he may replenish his bait-box; for if the bait is in good preservation, I have often known a brace of Pike to be taken with one bait when used with care and skill.

There is another description of gorge-hook, known as the weed-hook, which is used in weedy places, and is very successful in finding fish. The hook is the same shape as the ordinary gorge-hook, but it has no wire to it, the gimp being fastened to a ring at the end of the lead, which is about an inch and a half in length; to bait it, the gimp is turned back on the lead, which is then pushed into the mouth of the bait, the points of the hooks fitting close to the sides of the mouth, and the gimp coming out between the hooks; the lips are then sewn up with a needle and thread, to prevent the lead coming out; it is then 
fastened on the hook-swivel at the end of the trace, and is ready for use. A sketch is given at page 70 .

The reader will observe that when baited the bait sinks in the water head-first, and when drawn out comes up head-first, thus keeping clear of all weeds, amongst which it may' be used with impunity.

When you have a run, after giving him time to gorge, (from five to ten minutes, according as the Jack seem on the feed or not,) strike sufficiently sharp to break the thread with which the mouth was sewn up, so as to allow the hook to turn inside the Jack; a sharp strike will accomplish this. You have now only to play and land him as usual.

Another description of gorge-hook for use among weeds is the spear-hook; the shape is the same as the first, the only difference being that there is a pointed steel wire barbed like a harpoon projecting from the lead, instead of the twisted brass wire shank. The gimp is fastened to a ring between the hooks. The spear-hook is baited like the weed-hook, the barbed point is run through the bait, entering at the mouth, which is generally sewn up, the hooks fitting close on either side. The barb keeps the bait firm on the wire, still the sewing makes it safer; the gimp comes from the mouth. This hook is used precisely like the one last mentioned, but is not always so successful, the Jack frequently feeling the point or 
barb of the wire when turning the bait in his mouth, and consequently dropping it.

The best baits for trolling are gudgeons, which may be carried in bran in a tin box having divisions in it; next to gudgeons in value as a gorge-bait are dace and roach.

\section{CHAPTER IX.}

HOW TO WORK THE GORGE-BAIT-DISTANCE TO THROW-TIME TO ALLOW FOR POUCHING, ETC.

THE gorge-bait is thrown precisely in the same manner as the spinning-bait, therefore follow the directions given, as regards throwing, in Chapter IV. There are various methods of handling the gorge-bait when in the water, but the following will be found the best. Begin by trying a few yards only from the shore; let the bait sink nearly to the bottom; now draw it gradually upwards, by raising the point of the rod and drawing in the line slowly, till the bait is near the surface of the water; let it sink again; now draw it up a little to the left or right; again let it sink, and draw it up slowly, and, stepping back a little from the water, work the bait nearer the shore. The next cast, throw a little farther out, working the bait up and down as before. Try near all 
beds of weeds and rushes, and in the quiet corners where there is little or no stream.

With a twelve-feet rod the bait can be thrown sixty yards, or even more; but these long throws are in general of no practical use, and are often done merely for the sake of showing off; while the bait is often injured, and for some time after it has fallen in the water cannot be worked in anything like natural motion; therefore shorter throws are generally more effective. Thirty yards will be quite long enough to throw, unless you wish to reach a particular spot a long way out which has some special attraction. This distance you can manage easily, causing the bait to enter the water in a slanting direction, and you can commence gathering up your line before the bait has got injured by hitching in any obstruction at the bottom of the water.

When you have a run, which you can soon tell by feeling the line pulled or tugged rather sharply, lower the point of the rod towards the water, and at the same time draw the line with your left hand gradually from the winch, so that nothing may check the Jack, or stop him running. When he stops, give him from seven to ten minutes to pouch the bait; but if the line shakes after he has laid still a few minutes, and the fish makes another run, wind up the slack line and play him secundum artem. If he has pouched the bait some time, it will probably be out of reach, and you must either cut it out 
after knocking him on the head, or bait another hook; the latter is decidedly preferable, as in cutting out the gorge-hook you generally disfigure the fish, besides being a great loss of time if the Jack are on the feed.

\section{CHAPTER X.}

SNAP-FISHING-THE ROD, WINCH, LINE, AND TRACE -THE LIVE-BAIT SNAP, SPRING SNAP, DEAD SNAP, ETC.

SNAP-FISHING is usually practised at those seasons when Pike do not feed with sufficient eagerness to pouch the bait quickly; but the great advantage this style of fishing possesses in the eyes of the true angler is that it enables him to return to the water all under-sized fish, which if taken with the ordinary live-bait tackle, he would be obliged to kill in consequence of their having pouched the hook. Unfortunately a large majority of fishermen seem to prefer quantity to quality, and bag every fish taken, no matter how small, regardless of the fact that by so doing they are spoiling all future sport, both for themselves and others.

The rod should be rather stiff, to enable you to strike sharply; the winch and line 
have been already described; the trace and float are the same as in ordinary live-bait fishing. Many anglers prefer twisted gut for the trace instead of gimp, as it is much stronger and does not show so conspicuously in the water; others, myself among the number, consider salmon-gut quite strong enough for any Pike.

Snap-hooks may be divided into two classes, those used with a live-bait and those used with a dead bait, (the former require a float, but the latter are generally used without one,) and these are again divided into those that spring open when the fish is struck and those that do not.

Of those that are used with a live-bait, and that do not spring open, the following is the best; and is known as "Otter's live-bait snap."

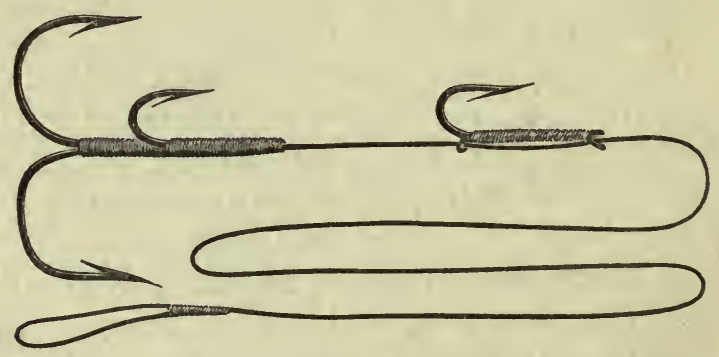

It consists of four hooks, two large ones brazed back to back, and a smaller one brazed about the middle of the shanks of the larger ones, and pointing straight out from them as above; 
these are all mounted on a piece of yellow gimp, with a lip-hook made to slide up and down at pleasure on the gimp, so as to accommodate a bait of any length. It is used thus - the small hook is inserted under the back fin, the point coming out at the other side; care must be taken that it does not go in so deep as to injure the bait; the large hooks lay on the back of the bait; the lip-hook is then run through both lips, and the bait is ready for use. If carefully done, the bait will swim as strong as in ordinary fishing. When the Pike seizes it let him run a yard or so to make sure, and then strike sharply the contrary way.

The "Francis" snap is similar in form, having a triangle at the end; but the hooks are all of one size; and the small lip-hook, instead of sliding, is fixed; this is hooked under the back fin of the bait, and the triangle hangs down at the side.

The "Pennell" snap is in the same form, but instead of being hooked under the back fin, it is threaded across the side of the bait with a needle under the skin from belly to back, and the triangle hangs below the bait. The objection appears to be that if there is a weed it must be caught, and if the bait has to be thrown far, the skin of the bait must be torn off. The "Francis" style of baiting is by far the best.

Another style of snap, much liked by some 
anglers, is formed of two triangles tied a couple of inches apart at the end of a foot of gimp. The upper one is fixed under the back fin, and the end triangle is hooked, sometimes under the shoulder of the bait, and at other times under and behind the ventral fin. A handsome Pike of thirty-five pounds was shown at the Westminster Aquarium Exhibition, which was caught on this tackle.

The "Saddle" snap is shown in the sketch, as baited. It is a very effective tackle: the bait hangs on the small hook which is inserted under the back fin, and a triangle is suspended on either side of the bait.

The next we come to is the Spring snap, of which this is a sketch-

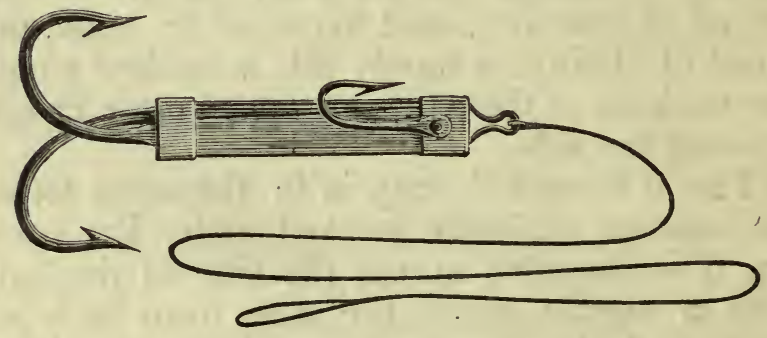

On examination, you will observe that the two large hooks have their shanks flattened, and the shanks lay one over the other between two steel wires; the ends of the shanks are riveted together, and have a small hook fastened to them, also a narrow band which 


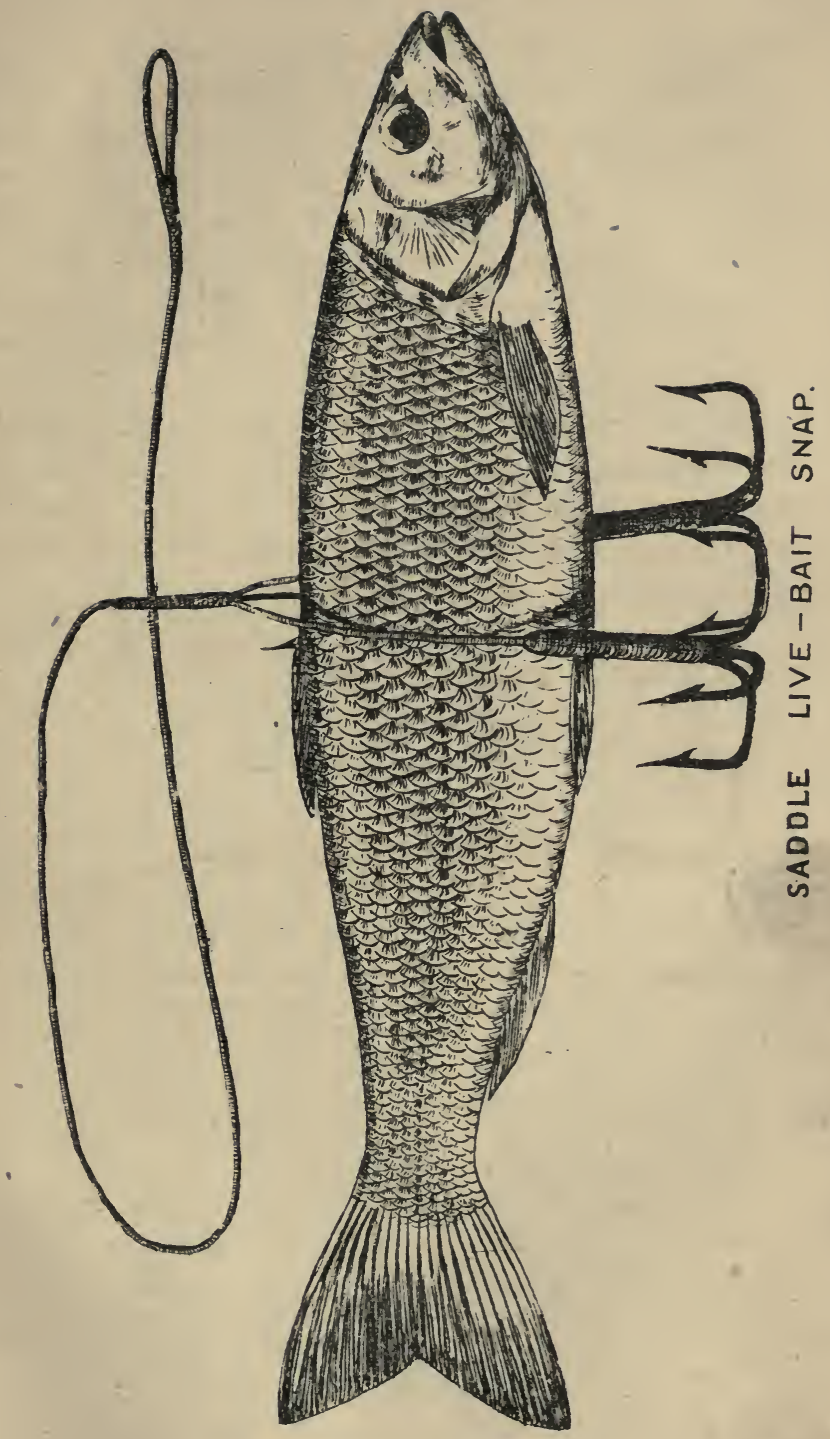



encircles the wire pillars; these last are fastened together at one end by a steel band, through which the shanks of the hooks slide, when they spring out on a fish being struck; the other end of the pillars is formed into a ring, to which is attached the gimp, having a loop at the end ready to fasten to the hook-swivel of the trace.

To bait the spring snap, the small hook is inserted under the back fin of the bait, and the large hooks hang at the side. When the Pike takes the bait, strike sharply, and the large hooks fly out, the flat shanks sliding easily between the pillars. This snap may be used either with a live or dead bait.

We now come to what are called the Dead snaps - that is, those that are used with a dead bait. Of these the first is the dead-snap with one hook; to bait this you require a baitingneedle. The hook, a long-shanked No. $\mathrm{r}$, is tied to a foot of stout gimp, looped as usual at the end; attach the loop to the needle, and enter the point of it in the side of the bait about the end of the back fin, bringing it out about a quarter of an inch from the gill; enter the point again at the gill, and bring it out at the mouth; draw the gimp through till the hook lays close to the bait, point upwards; now take a pointed bead-lead with a ring at the end, pass it down the gimp, and place it inside the mouth of the bait; sew the mouth up, and it is ready for use. 
$A$ very neat and effective snap may be made by using another hook in addition to the last, to be employed on the other side of the bait; the second hook to be on short gimp just long enough when looped to reach to the nose of the bait. The short hook is threadled first, in the same manner as the dead-snap, with one hook, leaving the loop just inside the mouth; the long gimp hook is then to be threaded in the same way on the other side, and the needle passed through the loop of the short hook, so that when the gimp is drawn up and the long hook is in its place, the loop of the short hook is secure on the gimp of the long one; the bead-lead is then run down the gimp, and sewn in the mouth of the bait as before.

The next is the dead-snap with two hooks, which is used thus: take one of the ordinary double hooks used in live-bait fishing, and, attaching it to a needle, enter the point at the vent of the bait, and bring it out at the mouth; fix the bead-lead before described in the mouth, and sew it up; it is now ready to fasten to the trace.

The next is the snap with three hooks, which is baited the same as the one last mentioned; the triangle lays inside the vent, the hooks projecting on either side. This is known as the "Howse" triangle, and in lakes containing large Pike will be found very effective as soon as the weeds get rotten; use rather a large bait-either roach or dace. 
The dead-snap with four hooks is used in the following manner: at one end of a piece of stout gimp is securely tied a No. I hook; an inch further up the gimp tie another hook of the same size; loop the end of the gimp. Now take a piece of the same gimp four inches long, and tie two other hooks to it the same as the first two; loop the end of this also. To use this, put the loop of the short gimp under one gill of the dead-bait, and bring it out at the mouth; now do the same with the long: gimp at the other side of the bait, running that, however, through the loop of the short gimp also; now run a bead-lead down the long gimp, and sew it in the mouth of the bait as usual. 


\section{CHAPTER XI.}

SPINNING FOR TROUT AND PERCH-THE ROD AND TACKLE REQUIRED-BAITS, ETC.

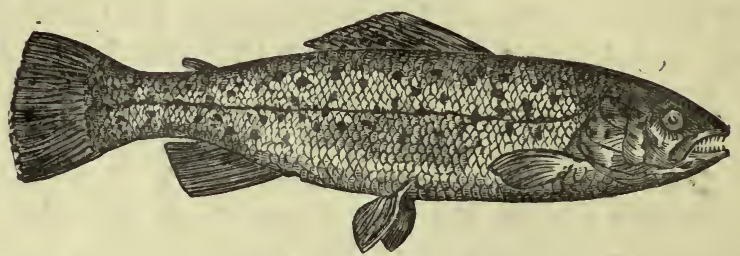

The Trout (Salmo Fario).

This style of fishing is much practised in the Thames, with occasionally great success; early in the morning, and towards sunset, are generally the best times. When dropping down the stream quietly in a punt on a fine summer's evening, while the setting sun tinges the distant water with gold, the Trout may be observed feeding on the shallows, and driving the minnows and other small fish in shoals towards the shore, being as voracious in that respect as their mortal enemy the Pike; their mouth is admirably adapted for the purpose, the jaws and tongue being studded with small teeth; they are thus enabled to destroy multitudes of small bleak, minnows, and gudgeons.

Next to the lordly Salmon, to which, to my mind, it is quite equal in beauty, the Trout may be considered the most game of freshwater fish. The reader should observe a first- 
rate Thames spinner standing on the top of a weir, (which requires a strong head and good nerves,) casting his bait into the foaming waters below him, then gathering up the line with the thumb and little finger of the left hand, throwing out the spinning bait from a twelve or thirteen feet rod with the right hand, at the same time letting the gathered line go, and spinning the bait across the eddies in a masterly manner, while the left hand is again collecting the line for another throw. All this should be seen to be admired and imitated, for no description can do it anything like justice. Who that has ever experienced it can forget the first rush of a noble Thames Trout in full season, especially if the angler be spinning from a weir? He dashes down the run, some sixty yards or so, like a flash of lightning, making the line whistle through the rings, and as if determined to carry all before him; now he rises to the surface, and, springing out full a yard, throws a somersault in the air, and tries by that means to rid himself of the hooks; but the skilful angler frustrates this little device by lowering the point of the rod, and meeting him half-way. By careful management he is at last tired out, and his captor, taking advantage of a moment's quiet, descends from his position on the weir, and safely lands his prize on the grassy bank below.

The law allows Trout to be taken in the Thames after January; but they are not in 
season until April, on the first of which month the spinning season commences, and ends in September. In the Lea, and almost all other rivers, the season does not begin till the first of May. In nearly all, the Perch season commences in June.

Spinning for Trout and Perch is practised in precisely the same manner as for Jack; finer tackle, and much smaller baits and flights of hooks, must, of course, be used.

The rod I use is of mottled cane, about twelve feet in length, in four pieces, and with extra tops. The rod should be light, and rather springy, as the bait and trace being rather light (unless when fishing the tails of weirs), the spring of the rod will be found of great assistance in throwing the bait.

The bronzed check-winch is the best for spinning; it should be sufficiently large to carry eighty or a hundred yards of fine prepared running-line, which should be as fine as possible, having due regard to safety; in the Thames, and similar large rivers, a hundred yards will not be found too much, but in small rivers the length of the line may be proportioned to the water.

We now come to the Trace: this should be of gut, with four swivels, and from eight to thirteen or fourteen shots (according to the depth of the water and strength of the stream) in the middle of the trace, which in length should be a couple of yards. In the Thames 

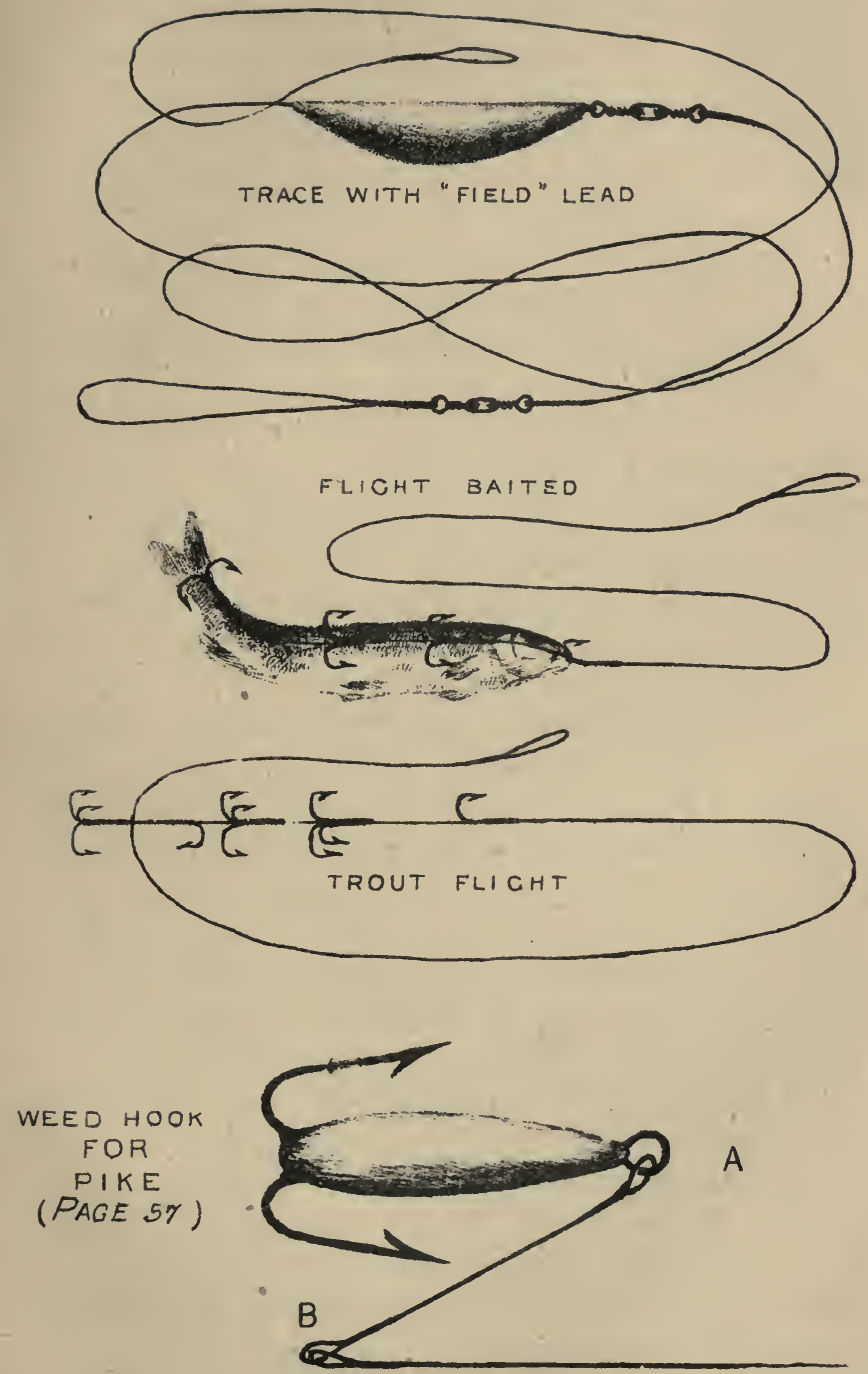

I should recommend the same gut-trace mentioned in Chapter II., with the hanging "Field" lead; but for smaller rivers a trace as given in the annexed drawing, with the "Field" lead on the gut, will be found very

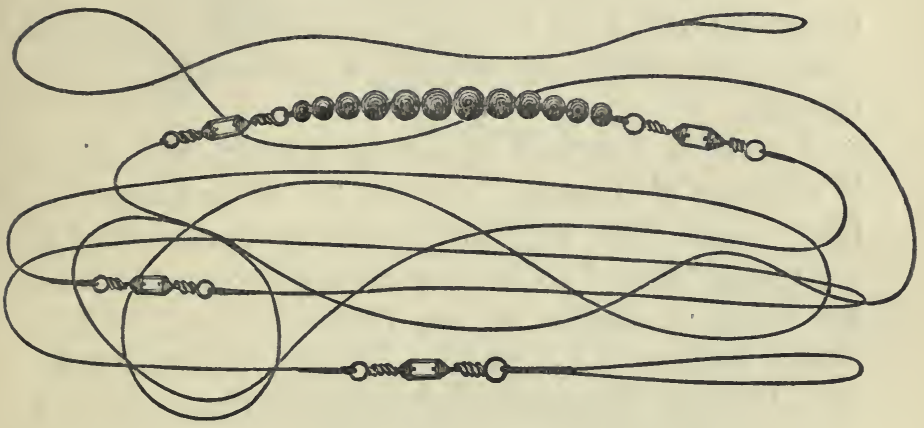

useful. In small, clear rivers, such as the Colne, none but the very finest gut should be used for the flights of hooks and traces, which should have less shots in proportion; in such streams three or four will be quite sufficient.

The flights of hooks used for Trout and Perch are precisely the same as those mentioned in Chapter II. for Jack ; the only difference being, that they must be made very small, and on fine gut, to suit the baits, which vary from two and a half to three and a half inches in length. And here I may mention that it is no uncommon occurrence to take at the Thames weirs Chub of three to five or six 
pounds weight, with the spinning-bait. Large Barbel will also occasionally take a spinningbait beneath the foam, and the eddies and corners of the weirs should be carefully spun for Perch.

The Water-witch, mentioned on page 20, mounted on gut, to carry a minnow or small gudgeon, will be found a first-rate Trout tackle.

There is another spinning tackle, known as "Hawker's Tackle," it is in this form": a large and fine minnow trolling hook, No. I size, is whipped to a length of gut; about half an inch, or rather more, from the end of the shank of this is whipped a lip-hook, size No. 8 ; and to the lip-hook and length of gut is also fastened a short piece of gut of sufficient length to reach to the end of the large hook. A small triangle is now whipped to the end of the short piece, and the tackle is completed by looping the long gut.

To bait it, the point of the large hook is inserted in the mouth of a large, bright minnow, which is now to be threaded up the hook, the point of which is to be brought out at the centre of the tail. The minnow is now to be pressed into natural form on the hook with the thumb and finger; the small lip-hook is run through both lips, and the bait is completed for use by sliding down the gut a small hollow lead cap, of a sugarloaf shape, which fits close on the nose of the minnow. 

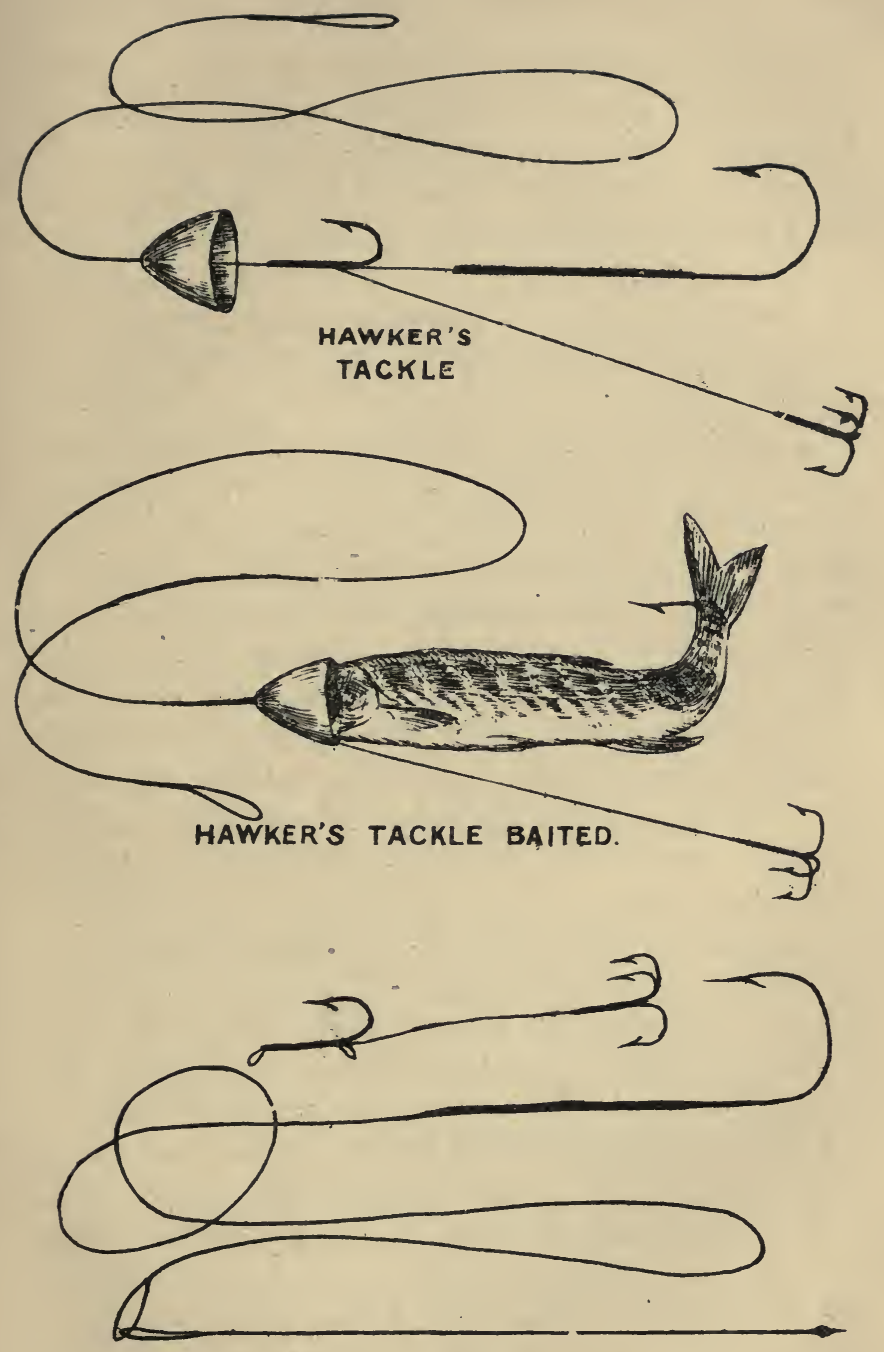

FRANCIS' TACKLE 

The triangle on the short gut flies loose over the tail. The only fault of this tackle is that the young angler will find some little difficulty at first in placing the bait neatly on it ; otherwise it is excellent, as no weight is required on the trace.

An improvement on this is the old pattern "Francis" tackle, a drawing of which is annexed. The large hook is attached to a baiting-needle, which is then entered in the centre of the tail of a minnow or other small fish, and brought out again at the mouth; the gut being brought through till the large hook is entirely inside the minnow, the tail of which thus receives its proper curve. Remove the needle, and pass the long gut through the small loops on the lip-hook, which being run through both lips will cause the bait to appear much the same as "Hawker's," but without the lead cap.

No. 8 , at page 22 , is baited thus: the lead is pushed down the throat of the minnow, the lip-hook is passed through both lips, and the first triangle is fixed in the back, just beyond the dorsal fin, so as to make the bait spin.

The baits for small streams may be either minnows, or small, bright gudgeons. I prefer the latter, as they spin better and last longer, whereas the minnows soon tear, and become useless.

For larger streams I prefer a small bleak, which has, when properly placed on the hooks, 
a very bright and star-like appearance in the water, although, like the minnow, it soon wears out, unless used with great care.

The bait should be placed on the hooks with a scrupulous regard to its spinning truly, as I have always found that the better the bait spins, the better the Trout likes it, and, as a matter of course, the greater the chance of success.

All the artificial baits mentioned in Chapter III. may be used for Trout and Perch, when made on a small scale, and mounted on gut. The artificial minnow, spinning by means of the pectoral fin, and mounted on gut in a similar manner to the one described at page 24, I have found the most successful, killing with it large Trout and Perch, when they had decidedly refused the natural bait.

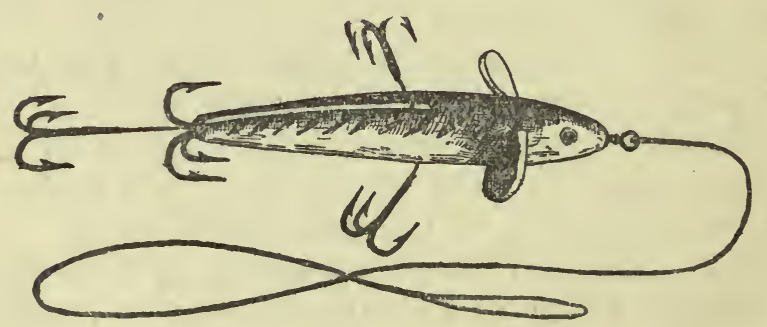

The "Devon," " Angel," or "Totness" minnow is a metal bait, sometimes used entirely bright for coloured water, or with the back painted brown for bright streams. It 
will be noticed that the bait is divided lengthways in the hinder half, the two flying triangles projecting on either side through the division. The bait being loose on the mounting, when a fish is struck. it will often be found that the bait is blown up the line, leaving the hooks alone in the mouth of the Trout. They are made in various sizes, some being half the size of the drawing, for use in small brooks. The swivel is just inside the mouth of the bait, but it is better to have two or three more on the regular gut trace.

Trout delight in swift clear streams running over gravelly bottoms, but are more frequently found by the side of the stream, in the eddies, than in the midst of it. Tumbling bays and mill tails are also their favourite haunts. The larger Trout often lay beneath hollow banks in the deepest parts of the river. The junction of rapids, caused by the water washing round an obstruction in the midst of the stream, is a likely place to run a Trout; the largest Perch also are found in eddies near a rapid current.

All Trout have their own haunt or place of retreat, generally some large stone or root of a tree; each fish appearing to possess its own special portion of the stream, and rarely trespassing on that belonging to a neighbour. When one of these sections becomes vacant, a fresh occupant soon takes possession, and thus it is that an angler knowing a river, and aware 
of the position of these haunts, has such a decided advantage over another without such knowledge, however skilful he may be in other respects. The colours of Trout will vary in the same waters; those that lie hidden under cover of the trees, or beneath overhanging banks and bushes, are much darker and yellower than those that are found in the unshaded stream with clear sandy bottom, which are altogether as silvery and bright. In some rivers they rarely exceed a couple of pounds in weight, but in some of the Welsh and Irish lakes they grow to a great size.

A distinguished member of another branch of the Trout family, Salmo ferox, which weighed thirty-nine pounds and a half, was taken in the River Awe in 1866; in many of the Scotch lochs they run very large, and are principally taken with the spinning-bait.

The Thames still contains splendid Trout of great weight, but these are getting every year more and more scarce and shy; the old weirs with their plank aprons, under which they used to live, are being exchanged for concrete and stone, and the want of these old covers and hiding-places, together with the clearance of many old stumps and roots, has considerably injured the Thames as a home for large Trout; and although the stock of small ones is constantly receiving additions in the shape of importations from High Wycombe and elsewhere, still these are not the old veritable 
Thames Trout, our friends of years gone by. My largest weighed nearly thirteen pounds, but they are occasionally taken of much greater weight. One was taken in May 1863, in Marlow Weirpool, weighing fifteen pounds; another, of fourteen pounds, at Teddington Weir, in 1869 .

If the water should be clear, and you should be able to see a Trout come at the bait, do not hurry, but continue to spin steadily, so as not to check the pace at which the bait is travelling, or the Trout may suspect something wrong, and stop short. Observe not to strike until you feel that he has taken the bait, and then you will probably do so instinctively; so that it is somewhat superfluous to tell you, as one writer does, to strike a second time to make sure; the first strike will generally hook your fish, but the second strike will, in all probability, either break the gut or your hooks, if these be fine. When hooked, keep a steady gentle strain on your fish, giving line only when necessary; but be prepared for a rush if the Trout is a large one and the stream sharp. Get below your fish if possible, as nothing is so likely to cause you to lose a fish as to allow him to pull away from you down-stream with his head up and towards you. As he rushes away, hold him gently but firmly, not straining on him too much; after checking him a few times when you find his struggles becoming weaker, guide him within reach of 
the landing-net, and be careful to use this gently, so as not to frighten your fish at the last moment when you might possibly not be prepared for a violent plunge; but sinking your net, bring him quietly over it, then lift it steadily and secure your prize.

Before closing this chapter on Trout-fishing, I must remark that there is a great deal more necessity for attention to the colour of one's clothes when angling than many people seem to imagine. Of all the senses of Trout, that of sight is I am quite sure the most acute. I have noticed this continually; once, I remember, when fishing in the Lea with a friend, we observed a nice fish of about four pounds weight lying close to the wall on the apron of a weir, over which very little water was running, but there he lay waiting for insects dropping from the overhanging bushes or stray minnows wandering from home. Telling my friend to watch his movements, I crossed the weir bridge, crouching so that I could not see him; but still he saw me, owing to the refraction of the rays of light, and, slipping back almost imperceptibly, he gradually reached the edge of the apron and slowly sank into the deep.

Another time, I was using an artificial minnow in a mill-tail, standing behind a low fence and fishing over. Knowing what an extremely likely hiding-place for a good fish is formed by the long wooden apron, with 
its partially decayed planking under which the Trout lie perdues, I dropped my minnow lightly in close to a pile at the end of the sill, and drawing it rather sharply past, out came a spotted beauty of over five pounds weight, who at the same moment caught sight of either me or my rod. Back he darted; but leaving him a short time to recover his equanimity, I tried him again, with the same result, no less than five times; at the sixth time, either his hunger had increased, or he was becoming used to the occasional sight of the rod, for he forgot his prudence, and gave a thoroughly ferocious snap at my poor little minnow, but, much to his disgust, instead of taking the minnow, the minnow took him, and his happy hunting-grounds knew him no more.

Never wear any clothes for fishing that are of a decidedly striking colour,-a tall black or white hat is certainly not to be recommended; a suit of dark grey or neutral tint is preferable. If you are fishing a small stream, take advantage of every bush at the side of the water which will afford you any cover; or if there is nothing of the kind, stoop or crawl as well as you can, so as to keep out of range of the Trout's vision.

A friend of mine who used to fish a small Welsh stream which in parts was not much wider than a ditch, could catch more Trout-and those of far larger size- - than any one else who fished the same water, simply through paying 
attention to this rule. He used a rather long, light, and stiff rod, with fine line, and a small Totnes minnow. Instead of walking direct up to the river, knowing where the holes were, he would crawl up on his hands and knees till within reach of the water; then, dropping the bait gently above the hole, he would draw it sufficiently sharp down-stream to spin it properly, and used to catch Trout from parts of the brook that many others would have passed.

For the same reason of keeping out of sight as much as possible, practise throwing your spinning bait, if fishing from a punt, whilst sitting down,-not on a chair like a Roachfisher, but seat yourself on the well,-and spin carefully, right and left, over every likely bit of ripple or eddy where a fish might be expected to be waiting for food. If you have a puntman with you who is up to his work, he will manage the punt without splashing and disturbing your fish, but will drop you down a yard or two at a time, by means of the weight and line, whilst you spin on either side, till you reach within a convenient distance of any spot where you know a fish is usually to be found, or has been seen to feed: then wait for your fish, trying for him steadily and carefully. Be on the watch for any other stray fish that may be about, and take notice of his haunts and times of feeding, for use on another occasion, so as to know how to approach with- 
out being too much exposed to the sight of the Trout.

On the last day of the Trout season in the Thames 1877 , I was landing a Pike on one side of the river, when I saw the rise of a Trout under the opposite bank some distance down. Punting across, we dropped quietly under the bank till we got immediately above where my spotted friend had just been chasing the small fry. We kept there perfectly still for about half an hour, till he fed again; and then over he rolled within three yards of the punt, a bright little beauty of about five pounds. Again he came up a little further off, driving a fish ; but although I threw at him with a spinning-bait, hitting him on two occasions, he was too intent on his own fish, and eventually secured it; so after devoting close upon two hours to him, I was reluctantly obliged to forego the pleasure of landing what would have formed a very good wind-up to the Trout season of 1877 .

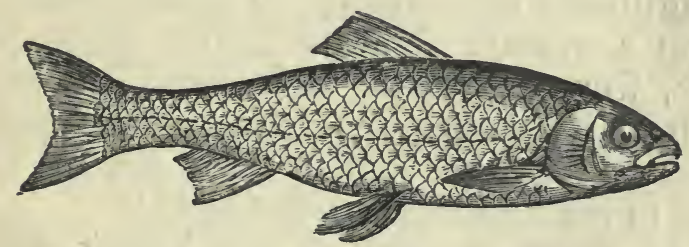

THE DACE (Leuciscus vulgaris).

Live-baiting for Trout is occasionally practised with some amount of success in the 
Thames and other large rivers. A small lively dace or bleak is used, on a proportionately small "Otter" snap mounted on gut; this is used according to circumstances, either with or without a float. If a float is used, it must be very small-just sufficiently large to keep the bait at about the requisite depth; one of the "Pilot" floats mentioned at page 38 will be large enough for the purpose. The running-line must be very fine, so as to sink as little as possible; and the bait should be allowed to work down-stream to where a Trout has been noticed feeding. It is then manipulated about the place in as attractive and skilful a manner as possible. On hooking the Trout, keep your line clear, in readiness for a rush, and do not hold him too tightly. I must confess, however, that I do not admire the idea of live-baiting for Trout; years ago such a style of fishing was only practised sub rosâ. But times have altered since then, and it is now considered almost as legitimate as spinning. I cannot even now forget a remark I heard nearly thirty years since, from one of the old school of Thames puntmen: speaking in a disparaging manner of a confrère, he said, "Why, sir, he takes most of his Trout with a live-bait!"

The Perch is such a well-known fish as hardly to need a description. He is a thick broad fish with a hog-back, head rather small in proportion, and a large mouth well furnished 
with small teeth in addition to those in the throat. The tail and ventral fins are a bright vermilion in colour; the pectoral and dorsal fins are brown. There are two fins on the back, the one nearer the head being armed with strong spikes, extremely sharp at the points, which it erects when alarmed or attacked. The angler, therefore, should be careful not to have his hands pricked by any of these points when unhooking a Perch: I have known it to have, occasionally, extremely unpleasant, not to say rather dangerous results. The Perch is covered with strong scales, and is of a bronzy green on the back and sides, down which are several dark stripes reaching from the back nearly to the belly. As regards his habits, he is socially gregarious, and remarkably imitative in the matter of taking a bait. Perch are to be found in the eddies of weirs and mill-tails, also in deep holes about bridges. Close to the camp-sheeting at the side of a weir, or in the backwater at the foot of the spurs of it, will be found good places to use the spinning-bait; taking care, however, not to let the undercurrent carry the bait under the sill of the weir. As regards artificial baits, a very small spoon is often successful, but I prefer a minnow, or small artificial parr. For catching minnows for bait, the minnow-trap will be found very useful; consisting of a very clear wide-mouthed glass bottle, over the mouth of which is fitted a movable cap of 
perforated zinc, through which the stream runs, agitating a small bunch of scarlet worsted suspended inside. The minnows being thus attracted, collect about the end of the bottle, working their way into the interior through a small opening in the centre of the bottom of the bottle. Bearing in mind the inquisitive nature of minnows, and how they usually swim in shoals, you will in a very short time, if in a favourable position, have a few dozens in the trap. Remove the zinc cap, take out the minnows, refix the cap, and it is again ready for work. A description of the minnow-trap is also given in the Rev. J. J, Manley's capital work "Fish and Fishing," and a drawing of it in use will be found in my "Modern Angler." When emptying the trap, should any sticklebacks have worked their way in, be careful of the sharp spines with which they are armed, and which must be cut off, if you are compelled to use them as bait, through scarcity of minnows.

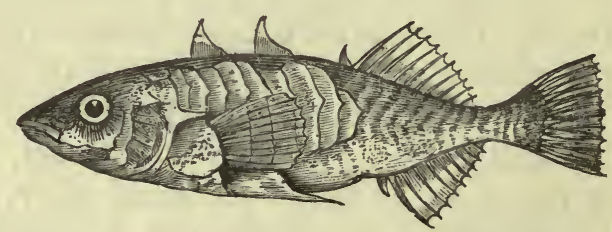

The Stickleback (Gasterosteus Semiarmatus). 
NOTICE OF REMOVAL.

J. C. CORDING \& CO., (Proprietor, GEORGE WILSON,) FROM 231, STRAND, (Five doors West of Temple Bar,)

TO 19, PICCADILLY (Corner of Air Street).

THE ORIGINAL MAKERS OF

VENTILATED

WATERPROOF

COATS,

FOR

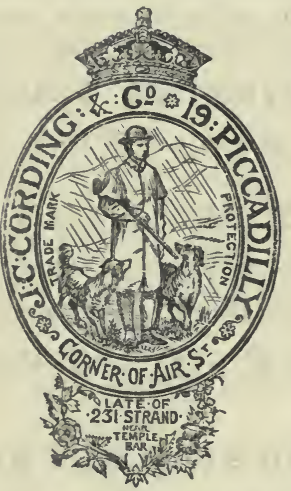

RIDING,

WALKING, and

FISHING.

See Field, July $\mathbf{I} 7$ and 3I, I869.

CORDING'S FISHING BOO'TS ARE CELEBRATED FOR THEIR SOFTNESS.

THEIR

FISHING STOCKINGS \& BROGUES ARE UNEQUALLED.

WATERPROOFS FOR THE TROPICS ARE GUARANTEED.

NO CONNECTION WITH ANY OTHER HOUSE.

THE ORIGINAL BUSINESS CARRIED ON AT

19, PICCADILLY, LONDON. 


\section{SUDDEN MOURNING.}

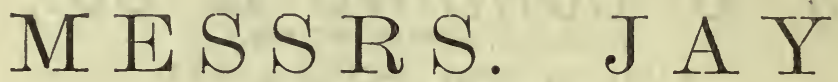

Are always provided with

EXPERIENCED DRESSMAKERS AND MILLINERS

Ready to travel to

\section{ANY PART OF THE KINGDOM,}

Free of Expense to Purchasers, when the emergencies of sudden and unexpected Mourning require the immediate execution of

\section{MOURNING ORDERS.}

They take with them Dresses and Millinery, besides Materials at Is. per yard and upwards

TO CUT FROM THE PIECE,

ALL MARKED IN PLAIN FIGURES, AND AT THE SAME PRICE AS IF PURCHASED AT

THE LONDON GENERAL MOURNING WAREHOUSE IN

REGENT STREET.

Reasonable Estimates are also given for

HOUSEHOLD MOURNING,

at a Great Saving to Large or Small Families.

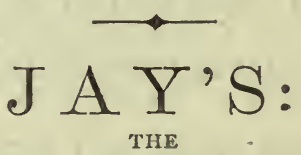

LONDON GENERAL MOURNING WAREHOUSE, REGENT STREET, W. 


\section{WM. R. SEELIE \& CO.,}

\section{iolime atterethants,}

Established 1840.

DIRECT SHIPPERS OF, AND AGENTS FOR, EVERY CLASS OF WINE.

75, MARK LANE, AND I9 \& 20, LONDON STREET, LONDON, E.C.

\section{CHAMPAGNES :}

Good Wines from 3os., Moet's 59s., Clicquot's 69s., Roederer's 7os. Pommery 7 Is. $6 d$.

SHERRY and PORT from 2OS. CLARETS from r2S.

PRICE LISTS AND SAMPLES ON APPLICATION.

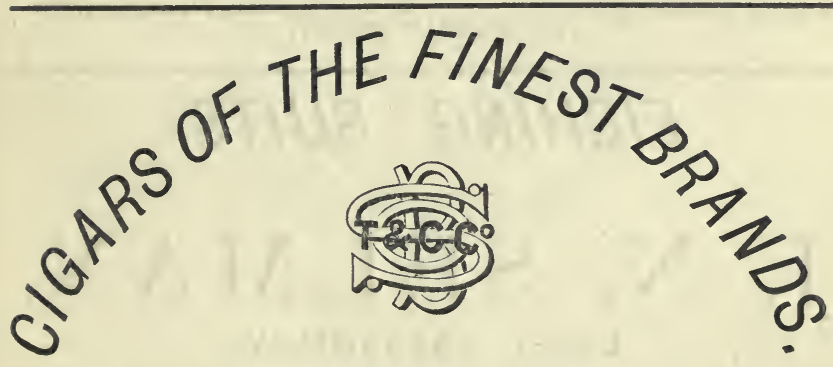

SPECIALITY FOR

MEERSCHAUM AND OTHER PIPES.

OLD BROAD STREEI

TOBACCO AND CIGAR COMPANY,

47, OLD BROAD STREET

(Corner of London Wall). 


\section{THE PROVIDENT CLERKS'}

Mutual Life Assurance Association.

(ESTABLISHED r840.)

Chief Office, 27 (late 15), MOORGATE STREET, LONDON.

The whole of the Profits are divided among the Members every five years. The Association is not confined to Clerks, but includes among its Members EvERY CLAss OF SOC1ETY.

Dec., 1877 .

Prospectuses and every information on application as the Chief Office, 27, MookGATE STREET, London, E.C., or to the Agent.

\section{THE PROVIDENT CLERKS'}

General Guarantee Association, Limited.

Subscribed Capital, $£ 100,000$. Called-up and Paid, $£ 50,000$.

Prospectuses, Forms of Proposal, etc., may be obtained of the Agents, or at the Head Office, IONDON.

W. T. LINFORD, F.I.A., Secretary.

\section{THE PROVIDENT CLERKS'}

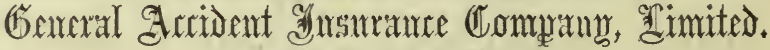

Subscribed Capital, $£ 50,000$.

To Assurers with the Provident Clerks' Mutual Life Association and the Provident Clerks' and General Guarantee Association, Accident Policies are issued at reduced rates.

W. T. LIN FORD, F.I.A., Secretary.

61, COLEMAN STREET.

\section{FISHING SUITS.}

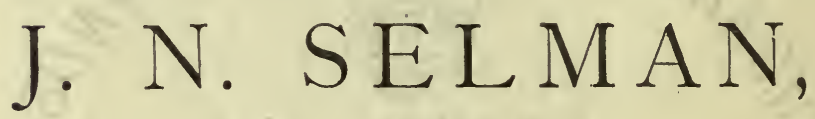

Late J. SALISBURY,

TAILOR \& OUTFITTER.

Spectulities îr Tfured Suits from 5 os.

UNIFORMS, LIVERIES, RIDING HABITS.

26, MOORGATE STREET, LONDON. 


\section{JOSHUA TURNER, HAT MANUFACTURER,}

52, GRESHAM STREET (Near the Bank of England).

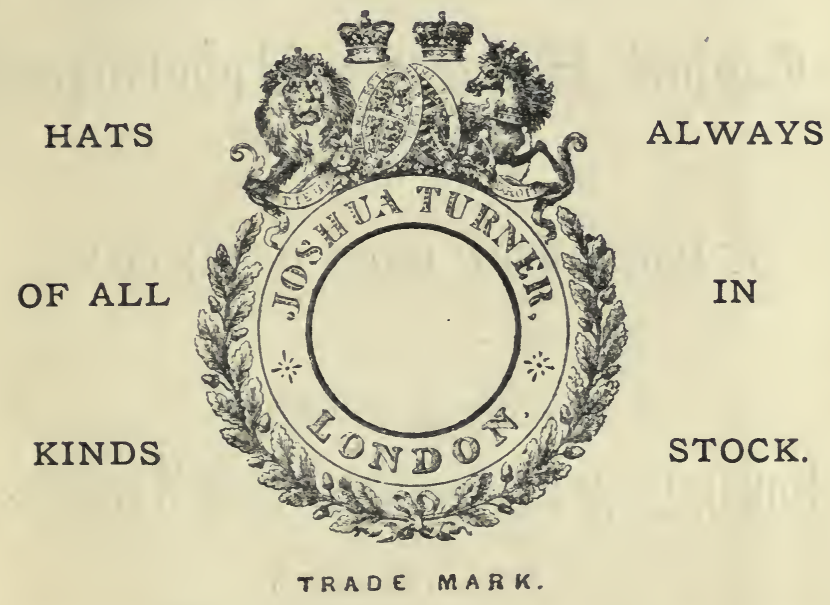

Gentlemen will find it advantageous to Purchase Direct from the Manufacturer.

Hats made to Special Instructions in a Few Days. And every effort made to suit Individual Tastes and Requirements.

A Very light Hat in a New bOdy for Summer Wear, I5s. 6d. 
G. M. \& H. J. STORY, IA, 2, AND 2A, COLEMAN STREET, 33, LONDON WALL, CITY,

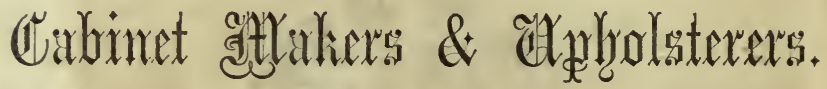
LARGEST SHOW ROOMS IN THE CITY.

\section{STORY'S PATENT}

Combination Bedstead \& Spring Matrress, Fifteen Shillings.

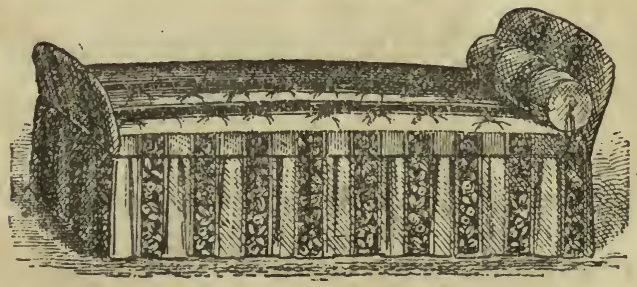

With Mattress and Bolster in Cretonne cover, as design, 31s. $6 \mathrm{~d}$. 




\title{
ADVERTISEMENTS
}

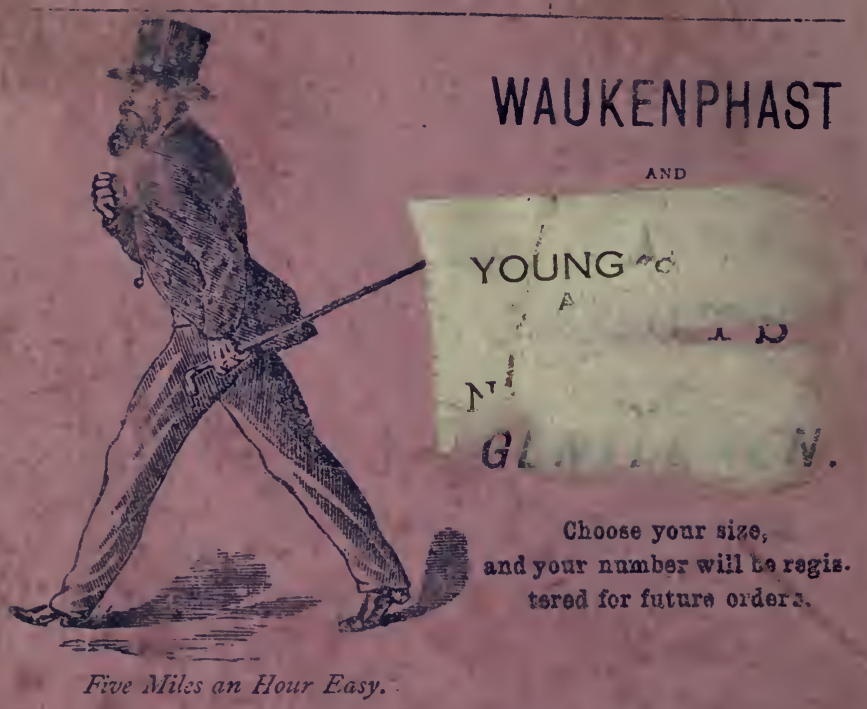

\section{9, HAYMARKET, LONDON, S.W.}

\section{WAUKENPHAST}

\author{
ANT) \\ COAs \\ $B 00 \mathrm{x}$
}

FOR

LADIES.

Autumn and Winter Boots for Long Walks.

Not a hindrance but a help to walking."

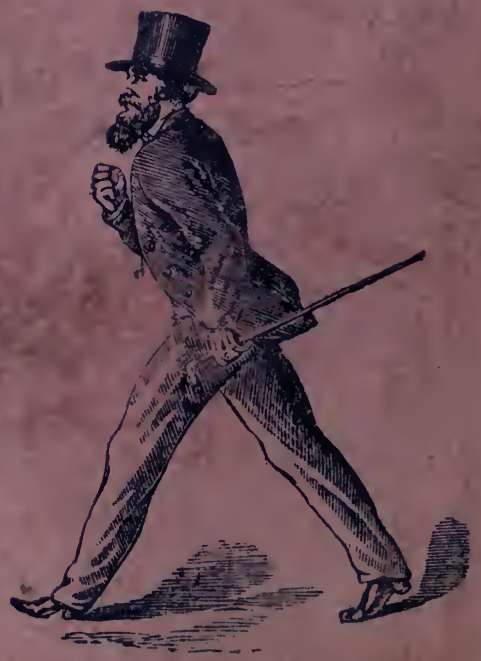

Five Mile. an Hour Ea.j 